NBER WORKING PAPER SERIES

\title{
SHADOW FUNDING COSTS: \\ MEASURING THE COST OF BALANCE SHEET CONSTRAINTS
}

\author{
Matthias Fleckenstein \\ Francis A. Longstaff \\ Working Paper 24224 \\ http://www.nber.org/papers/w24224 \\ NATIONAL BUREAU OF ECONOMIC RESEARCH \\ 1050 Massachusetts Avenue \\ Cambridge, MA 02138 \\ January 2018
}

We are grateful for the comments and suggestions of Andrea Eisfeldt, Tyler Muir, Laura Field, Xiaoxia Lou, Michael Pagano, Fei Xi, Haoxiang Zhu, and seminar participants at the University of Delaware and the 2017 Villanova University, Drexel University, Temple University, Lehigh University, and University of Delaware joint conference. All errors are our responsibility. The views expressed herein are those of the authors and do not necessarily reflect the views of the National Bureau of Economic Research.

At least one co-author has disclosed a financial relationship of potential relevance for this research. Further information is available online at http://www.nber.org/papers/w24224.ack

NBER working papers are circulated for discussion and comment purposes. They have not been peer-reviewed or been subject to the review by the NBER Board of Directors that accompanies official NBER publications.

(C) 2018 by Matthias Fleckenstein and Francis A. Longstaff. All rights reserved. Short sections of text, not to exceed two paragraphs, may be quoted without explicit permission provided that full credit, including $\odot$ notice, is given to the source. 
Shadow Funding Costs: Measuring the Cost of Balance Sheet Constraints

Matthias Fleckenstein and Francis A. Longstaff

NBER Working Paper No. 24224

January 2018

JEL No. G12,G13,G21,G23,G28

\begin{abstract}
$\underline{\text { ABSTRACT }}$
Recent theory suggests that balance sheet frictions and constraints faced by financial intermediaries can have major asset pricing implications. We propose a new measure of the impact of these constraints on intermediary funding costs that is based on the implied cost of renting intermediary balance sheet space. On average, balance sheet constraints add 81 basis points to intermediary funding costs, but the impact often exceeds 200 basis points during a crisis. We find that these balance sheet costs have real effects on intermediary investment decisions and asset holdings. Increases in balance sheet costs are associated with short-term increases in the use of derivatives, but longer-term declines in risk-taking by financial institutions. Balance sheet costs introduce a wedge between on- and off-balance-sheet investments which may help resolve a number of asset pricing puzzles.
\end{abstract}

Matthias Fleckenstein

University of Delaware

Lerner College of Business and Economics

310 Purnell Hall

Newark, DE 19716

mflecken@udel.edu

Francis A. Longstaff

UCLA

Anderson Graduate School of Management

110 Westwood Plaza, Box 951481

Los Angeles, CA 90095-1481

and NBER

francis.longstaff@anderson.ucla.edu 
Balance sheet space is treated like expensive real estate, available only to positions that can afford to pay rental fees that are now much larger. ${ }^{1}$

- Darrell Duffie

Bankers are blaming tensions in the repo world on the increasing cost of renting out their balance sheets. ${ }^{2}$

- Izabella Kaminska

\section{INTRODUCTION}

One of the fundamental principles of current asset pricing theory is that frictions and constraints that impact financial intermediaries may play a central role in determining security values. In particular, this literature demonstrates that balance sheet constraints faced by intermediaries - such as funding illiquidity or regulatory capital and leverage restrictions - may impact the stochastic discount factor used in the market. Key examples include Brunnermeier and Pedersen (2009) who examine the relation between funding availability and asset prices, Duffie (2010) who studies the effects of slow-moving capital on prices in financial markets, and He and Krishnamurthy (2013) who model how equity capital constraints faced by intermediaries may affect risk premia in financial markets.

An important implication of this literature is that asset pricing effects are directly related to how binding balance sheet constraints are on financial intermediaries. To date, however, it has been difficult to quantify the effects of balance sheet constraints on intermediaries. In particular, relatively little is known about how these constraints affect the cost of funding or the cost of capital of intermediaries over time. Clearly, having a measure of the impact of balance sheet constraints on intermediary funding costs would not only allow us to evaluate how binding these constraints are, but could also provide valuable perspective

\footnotetext{
${ }^{1}$ Darrell Duffie, Why are Big Banks Offering Less Liquidity to Bond Markets?, Forbes, March 11, 2016.

${ }^{2}$ Izabella Kaminska, Exorbitant Privilege and the Cost of Renting America's Balance Sheet, Alphaville, Financial Times, March 23, 2016.
} 
on their effects on asset pricing, market liquidity and stability, and risk sharing in the financial sector.

This paper uses a simple new approach to measure the effects of balance sheet constraints on these funding costs. This approach consists of comparing the direct financing cost of owning a security (on balance sheet) to the implied financing cost of taking a position (off balance sheet) in the same security through the derivatives market. Intuitively, by taking a synthetic position in the security via derivatives, an investor essentially "rents" balance sheet space from the financial intermediary providing the derivative. In equilibrium, the rental costs for the security should equal the sum of both the direct financing costs and the indirect balance sheet costs an intermediary bears by owning the underlying security as the hedge for the derivative contract. Thus, the impact of balance sheet constraints on intermediary funding costs - commonly known as balance sheet costs or shadow funding costs - can be measured directly as the difference between the implied financing rate in the derivatives market and the direct financing rate in the cash market.

We implement our approach by comparing the implied repo rates incorporated into Treasury note futures directly to the actual repo rates for Treasury notes paid by financial intermediaries. Both the Treasury note cash and futures markets are among the most liquid and actively-traded fixed income markets. An important advantage of focusing on these markets is that we can measure balance sheet costs over an extensive sample period ranging from 1991 to 2016.

A number of important results emerge from our analysis. First, we find that balance sheet costs are positive and significant throughout much of the sample period. On average, balance sheet constraints add 81 basis points to an intermediary's cost of funding. The funding cost impact, however, was as high as 200 basis points in the aftermath of the Asian debt crisis of 1997 and the financial crisis of 2008. To put these costs into perspective, we note that the direct cost of funding earning assets (defined as the total interest expense paid on deposits and other borrowed money as a percentage of average earning assets) as reported by the FDIC averaged about 256 basis points during the sample period. Thus, these indirect costs increased the average funding costs of financial intermediaries by nearly one third. Furthermore, these costs are multiples of typical FDIC deposit insurance assessment rates or the guaranty fees for agency mortgage-backed securities. ${ }^{3}$ Clearly, balance sheet costs of this

\footnotetext{
${ }^{3}$ For current FDIC deposit insurance assessment rates, see https://www.fdic.gov/ deposit/insurance/assessments/proposed.html. As examples of historical agency mortgage-backed security guaranty fees, see https://www.fhfa.gov/AboutUs/Re ports/ReportDocuments/GFee_Report_FINAL.pdf.
} 
magnitude could have first-order effects on asset pricing as well as significant real effects on the financial sector and the macroeconomy.

Second, we demonstrate that our measure of balance sheet costs is directly related to constraints faced by financial intermediaries. In particular, we find that these balance sheet costs are increasing in the amount of equity capital that financial institutions are required to hold. Furthermore, we find that balance sheet costs are positively related to measures of the cost of equity capital and the cost of unsecured debt for these financial institutions. We also find a seasonal pattern in which balance sheet costs decline at year end. This result is consistent with recent evidence that intermediaries may strategically manage their balance sheets in a way that temporarily reduces their apparent leverage at year end.

Third, we find that changes in balance sheet costs have significant real effects on financial intermediaries. In particular, we find that an increase in balance sheet costs is associated with significant declines in broker-dealer leverage, holdings of Treasury securities, and asset growth rates. These results provide direct support for Duffie (2016) and others who argue that constraints (such as the Basel III supplementary leverage ratio (SLR)) could reduce market liquidity as financial intermediaries reduce their security inventories in response to the higher capital costs.

Fourth, we also find that balance sheet costs have important effects on the use of derivatives by financial institutions. Specifically, we find that an increase in balance sheet costs results in a short-term increase in the use of derivatives such as interest rate swaps and futures. In the longer term, however, we find that an increase in balance sheet costs leads to a decline in interest rate swap notional and Treasury note futures open interest. These results are consistent with a scenario in which investors initially migrate from the cash market to the derivatives market when balance sheet costs increase, but then reduce their overall risk positions over time in response to higher capital costs.

Finally, we explore whether the balance sheet costs inferred from the Treasury cash and futures markets relate to the funding spreads between cash-derivatives pairs in other markets. In particular, we examine whether our balance sheet cost measure is related to interest rate swap spreads. Swap spreads represent the difference between the yield on a synthetic bond (receiving fixed on a swap) and the yield on a Treasury bond with the same maturity. We find that an increase in our measure of balance sheet costs is followed by significant increases in longer-horizon swap spreads. This result is important since it suggests that the funding costs associated with balance sheet constraints have the potential to reconcile a number of well-known asset pricing anomalies involving cash-derivative pairs, such as CDS contracts and corporate bonds (Duffie (2010)), deviations from covered interest rate parity (Brunnermeier, Nagel, and Pedersen (2008), 
Du, Tepper, and Verdelhan (2017)), and inflation swaps and Treasury Inflation Protected Securities or TIPS (Fleckenstein, Longstaff, and Lustig (2014)).

There is an extensive literature on how the various types of balance sheet constraints faced by financial intermediaries may affect asset prices. A number of recent papers have focused on the implications of collateral constraints, funding liquidity, margin requirements, leverage constraints, regulatory capital requirements, and other types of balance sheet frictions and restrictions for financial markets. Important examples include Kiyotaki and Moore (1997), Chowdhry and Nanda (1998), Basak and Croitoru (2000), Allen and Gale (2000), Xiong (2001), Kyle and Xiong (2001), Gromb and Vayanos (2002), Krishnamurthy (2003, 2010), Fostel and Geanakoplos (2008), Brunnermeier and Pedersen (2009), Adrien and Shin (2010), Holod and Kitsul (2010), Gârleanu and Pedersen (2011), Danielsson, Shin, and Zigrand (2011), He and Krishnamurthy (2012, 2013), Adrien and Boyarchenko (2012), Basak and Pavlova (2013), Adrien, Etula, and Muir (2014), Brunnermeier and Sannikov (2014), Kondor and Vayanos (2015), He, Kelly, and Manela (2016), and Klinger and Sundaresan (2016).

There is also a rapidly growing literature on the potential impact on asset prices and market liquidity of recent legal and regulatory measures including the Dodd Frank Act, the Volcker Rule, and the Supplementary Leverage and the Liquidity Coverage Ratios of Basel III. Examples include Adrien, Fleming, Goldberg, Lewis, Natalucci, and Wu (2013), Kiema and Jokivuolle (2014), Adrien, Fleming, Stackman, and Vogt (2015), Duffie (2016), Allahrakha, Cetina, Munyan (2016), Bao, O'Hara, and Zhou (2016), Baranova, Liu, and Noss (2016), and Adrian, Fleming, Shachar, and Vogt (2016). This issue has also been extensively discussed among industry participants and policy makers are actively considering the impact of these regulatory measures on market liquidity. Recent examples include the International Capital Market Association (2015) and Chen, Korapaty, and Swaminathan (2016).

This paper contributes to this literature in several ways. First, we provide strong evidence that the relative pricing of Treasury securities in the cash and futures markets is directly related to the balance sheet constraints faced by financial intermediaries. Second, we show that increases in balance sheet costs have real effects on the leverage, holdings of Treasury securities, and asset growth rates of financial intermediaries, as well as on the use of derivatives by market participants. Third, our measure of the impact of balance sheet constraints provides a metric for monetary policy authorities and others for evaluating the effects of capital regulation on financial markets. Fourth, our results provide a framework for resolving a number of puzzling asset pricing anomalies involving financial derivatives and cash market instruments. Finally, our results provide direct empirical support for the rapidly growing literature on intermediary asset 
pricing.

The results in this paper also provide new perspective on an important parallel literature that studies the financing rates incorporated into derivatives prices. Key examples include Brenner and Galai (1986), Ronn and Ronn (1989), Longstaff (1995), Krishnamurthy (2002), and Song and Zhu (2016). Other work on implied financing rates in derivatives prices includes Manaster and Rendleman (1982), Naranjo (2009), Omprakash (2014), Gunther, Anderson, and Goldberg (2016), and Golez, Jackwerth, and Slavutskaya (2017).

\section{IDENTIFYING BALANCE SHEET COSTS}

To illustrate the intuition behind our approach, imagine that an investor wishes to take a position in a financial asset. The investor typically has two ways of entering into this position. The standard approach is for the investor to take ownership of the asset by purchasing it outright. An important consequence of direct ownership of the asset is that it becomes part of the investor's balance sheet. This has major implications for many types of financial institutions, however, because on-balance-sheet assets introduce additional capital constraints. This is because on-balance-sheet assets often require financial institutions to set aside additional capital for these assets due to regulatory capital requirements.

Alternatively, the investor can take a position in the asset synthetically via the derivatives market using futures, total return swaps, or other types of contracts. A key feature of this approach is that it allows the investor to benefit from price changes in the underlying asset without having to take ownership or pay the full value of the asset up front. Thus, derivative contracts not only allow investors to take synthetic positions, they also provide synthetic leverage for those positions. ${ }^{4}$ Moreover, only the mark-to-market value of the derivative is placed on the balance sheet - the full value of the asset remains off balance sheet, which means in most cases that the financial institution must put aside less incremental regulatory capital when taking a derivative position than is the case for a cash position in the asset. ${ }^{5}$ For many investors, this means that taking

\footnotetext{
${ }^{4}$ For example, see Tuckman (2013).

${ }^{5}$ Under U.S. GAAP (FAS 133), swaps, futures, forwards, and option contracts are derivatives whose notional values are carried off balance sheet and only fair values recorded on the balance sheet. See FAS 133: Statement of Financial Accounting Standards 133, "Accounting for Derivative Financial Instruments and Hedging Activities," at: http://www.fasb.org/jsp /FASB/Document_C/DocumentPage? cid $=1218220124631 \&$ acceptedDisclaimer $=$ true.
} 
a synthetic position in the derivative market is far less capital intensive than an outright ownership position in the security.

Intuitively, by taking a synthetic position, an investor essentially "rents" the security from a financial intermediary instead of owning it outright. This transaction, however, typically requires that some financial intermediary purchase the underlying asset to maintain a hedged position. In this sense, the investor rents not only the security, but also space on the financial intermediary's balance sheet. In equilibrium, the cost of renting the security should equal the cost of owning the security. ${ }^{6}$ To make things concrete, consider the case of a financial intermediary taking a position in a Treasury bond. For this investor, the cost of ownership can be broken down into two components. The first is the direct cost of financing the position in the repo market. The second consists of the indirect costs imposed on the intermediary because of frictions and constraints such as margins, haircuts, regulatory capital and leverage requirements, funding illiquidity, and compliance costs. For clarity, we refer to these frictions and constraints generically as balance sheet constraints. Similarly, we refer to the indirect costs that balance sheet constraints impose on financial intermediaries as balance sheet costs (the equivalent term shadow funding costs is also used in practice). Thus, the total cost of ownership is the sum of the repo rate and the balance sheet costs. By contrast, the funding cost of taking a synthetic position in a Treasury bond is simply the implicit financing rate embedded in the derivative contract. In the case of Treasury futures contracts, this implicit financing rate is known as the implied repo rate.

Thus, comparing the rental cost of securities with the direct financing costs of ownership allows us to identify the balance sheet costs faced by financial intermediaries. In this paper, we estimate these balance sheet costs as the difference between the implied repo rates incorporated into Treasury note futures and the corresponding term repo rates for the underlying Treasury notes. Clearly, however, this approach to identifying the balance sheet costs of financial intermediaries could be extended to other markets.

${ }^{6}$ It is important to observe, however, that financial constraints may also play an important role in the rent vs. ownership decision. For example, Eisfeldt and Rampini (2009) show that when recovery rates differ between buying and renting, firms with higher default risk may prefer to rent. This issue is relevant since derivatives may receive priority in bankruptcy. See also Sharpe and Nguyen (1995). 


\section{BALANCE SHEET CONSTRAINTS}

As described above, we use the term balance sheet constraints in a broad sense to denote the many frictions and constraints that may impact an intermediary's cost of direct ownership of financial assets. In this section, we highlight several of the major categories of frictions and constraints that play a central role in the current regulatory and market environment. It is important to recognize, however, that these are only a few examples of the many types of constraints faced by intermediaries and do not represent a comprehensive list. Table 1 provides a timeline of some of the major market events and changes in financial regulation during the study period.

\subsection{Capital Requirements}

Capital requirements for financial institutions have increased significantly in recent years as a result of stricter regulation following the 2008 financial crisis. Both Basel III and the Dodd-Frank Act raised existing bank capital adequacy standards and introduced new requirements. For example, Basel III mandates a five percent equity-to-asset ratio for the largest U.S. banks (regardless of the risk of the assets, see Duffie (2017)), and also specifies stress tests and risk management practices (the appendix provides a detailed discussion of the Basel III framework). The Supplementary Leverage Ratio (SLR), introduced in June 2012 and finalized in July 2013, has been at the center of ongoing controversy. The SLR requires that large U.S. banks have a minimum of $\$ 3$ in Tier 1 capital for each $\$ 100$ of total non-risk-weighted exposures. Repo transactions have a risk weight of one in the total exposure measure, regardless of whether assets are given lower risk weights in calculating risk-based capital ratios. ${ }^{7}$ Duffie (2016) argues that the SLR requirement may have serious adverse effects on liquidity in fixed income markets. The appendix provides an example illustrating how a direct position in a Treasury security may materially worsen a financial institution's SLR compared to a synthetic position in a Treasury security via futures.

U.S. regulators tightened leverage requirements further in July 2013 by introducing the Enhanced Supplementary Leverage Ratio (eSLR). The eSLR increased the capital buffer above the three percent SLR to a minimum of five percent of Tier 1 capital divided by total exposures for a covered bank holding

\footnotetext{
${ }^{7}$ Total exposure is typically higher than total on-balance-sheet assets. For example, Allahrakha, Glasserman, and Young (2015) report that total exposures are 44 percent greater than total assets for the largest top-tier U.S. banks, and 27 percent greater for all large U.S. banks. In addition, banks are no longer allowed to net repo activity with non-dealer clients because short-term wholesale funding transactions must be reported on a gross basis.
} 
company and, in addition, any insured depository institution that is a subsidiary must maintain a minimum of six percent to pay out unrestricted bonuses and dividends. The eSLR applies only to U.S. bank holding companies with assets of at least $\$ 700$ billion or with assets in custody of at least $\$ 10$ trillion on a consolidated basis with all their insured banking subsidiaries. As of 2016, eight U.S. bank holding companies fit this description and the Basel committee classifies these as global systemically important banks (G-SIBs). ${ }^{8}$

The Dodd-Frank Act introduced the framework for systemically important financial institutions (SIFIs) in 2010. Financial institutions designed as globally systematically important bank holding companies must hold additional capital ranging from 1.00 to 5.50 percent or more of a firm's total risk-weighted assets. The Volcker Rule prohibits banks from engaging in proprietary trading with their own accounts and limits their ownership of (and relationship with) hedge funds and private equity funds.

Banks are subject to the Basel Capital rules as well as to regulations passed after the financial crisis such as the Dodd-Frank Act. Bank holding companies (BHCs) are subject to capital and leverage ratio requirements similar to those of banks. Bank holding companies are not subject to statutory prompt corrective action, but are subject to supervisory action and potential penalties by the Federal Reserve if they fail to meet capital requirements. Prior to 2004, broker-dealer capital requirements were primarily dictated by Security and Exchange Commission (SEC) rules. Since the introduction of the 2004 SEC Net Capital Rule and the SEC's Consolidated Supervised Entities (CSE) Program, broker-dealers have essentially been subject to the Basel capital rules. Moreover, after the financial crisis many large broker-dealers have converted to bank holding companies and, thus, are subject to bank regulations.

\subsection{Liquidity Requirements}

The Dodd-Frank Act and Basel III also impose balance sheet constraints through their liquidity requirements. For example, the Dodd-Frank Act narrowed the definitions of acceptable collateral and raised risk-weighted asset requirements. Two liquidity requirements that directly impact a financial institution's capital structure are the total loss absorption capital measure (TLAC) and the liquidity coverage ratio (LCR). The TLAC requires large banks to issue ordinary shares, subordinated debt, and other loss-absorbing securities equivalent to the minimum of 16 to 20 percent of their risk-weighted assets, and at least two times the Basel III leverage requirement of 3 percent. The LCR requires banks with over $\$ 50$ billion in assets to hold sufficient high-quality liquid assets (HQLA) to

${ }^{8}$ See http://www.fsb.org/wp-content/uploads/2016-list-of-globalsystemically-im portant-banks-G-SIBs.pdf. 
meet projected net short-term cash obligations over a 30-day stress period. In particular, this requirement implies that for assets to qualify as high-quality liquid, the assets cannot be financed by repo and must be available to the bank's treasury function to liquidate. ${ }^{9}$ Moreover, when a bank holding company funds a security position via repo, only outflows associated with the secured funding are used in determining the LCR and, thus, the costs of using repo transactions to finance asset positions increase. Allahrakha, Cetina and Munyan (2016), using data on tri-party repos, document that following the 2012 introduction of the supplementary leverage ratio, broker-dealers affiliated with bank holding companies decreased their repo borrowing but increased their use of repo backed by more price-volatile collateral. Furthermore, they argue that the announcement of the SLR rule has disincentivized those dealers from borrowing in the triparty repo market. The appendix also provides an example illustrating how a direct position in a Treasury security may materially worsen a financial institution's LCR compared to a synthetic position in a Treasury security via futures.

In addition to the LCR, the Basel Committee introduced the Net Stable Funding Ratio (NSFR) in January 2014 to promote funding stability by reducing overreliance on short-term wholesale funding and to mitigate funding risk across on- and off-balance-sheet items. Specifically, the NSFR requires banks to maintain stable funding for both on- and off-balance-sheet activities over a one-year stress period. The NSFR may significantly affect how banks obtain and provide short-term funding, in particular in the repo markets. That is because securities financing transactions are defined as loans, and secured lending to non-banks is treated in the same way as unsecured lending in terms of capital requirements.

\subsection{Funding Frictions}

Another potential source of balance sheet costs is the impact of funding frictions on financial institutions. For example, Johannes and Sundaresan (2007) describe how the frictions associated with marking-to-market and the costly collateralization of trading positions impact financial intermediaries in the interest rate swap market. Andersen, Duffie, and Song (2016) present a framework in which the cost to a dealer's shareholders of financing the cash required to collateralize trading positions creates a type of debt overhang problem that impacts dealer bid-ask spreads.

Market practitioners account for the cost of funding frictions through a variety of balance sheet valuation adjustments known generically as XVA adjustments. For example, market practitioners have introduced measures such as the

${ }^{9}$ See Section 22, p. 61530 of the U.S. final rule implementing the LCR, available at www.gpo.gov/fdsys/pkg/FR-2014-10-10/pdf/2014-22520.pdf. 
credit valuation adjustment (CVA) and the debt valuation adjustment (DVA) to account for credit risk, the margin valuation adjustment (MVA) to account for the funding cost associated with initial margin, the capital valuation adjustment (KVA) to account for the impact of regulatory capital, and the tax valuation adjustment (TVA) to account for the effect of taxation on profits and losses. Although controversial, some practitioners also use a funding value adjustment (FVA) to account for the cost of financing the cash required to enter and maintain asset positions. ${ }^{10}$ Andersen, Duffie, and Song (2016) report that the cumulative total FVA of major dealers in the markets was on the order of $\$ 10$ billion in 2014 .

\subsection{Spillover Effects on other Financial Institutions}

While many of the examples of balance sheet constraints discussed above relate directly to banks, bank holding companies, and broker-dealers, it is also important to recognize that these constraints have ripple effects that impact other types of financial institutions. Thus, the impact of balance sheet constraints is not limited to just those large financial institutions explicitly addressed in recent regulatory and legislative actions.

As one example, a 2015 survey by Ernst and Young finds that recent regulation has had costly spillover effects on the hedge fund industry: ${ }^{11}$

Hedge fund managers are experiencing the ripple effects of new regulations on banks and prime brokers, with hedge funds facing increased trading fees and broader changes to business relationships. . . . Regulations such as Basel III and Dodd-Frank have caused banks and their prime brokerage businesses to focus more closely on liquidity, balance sheet capacity and funding, resulting in changing economics for fund managers who finance trades through prime brokers. Twenty-nine percent of respondents said their prime brokers increased fees in the past year, and and additional 22\% expect an increase in fees within the next year. . . . Many primary brokers are becoming reluctant to hold cash for hedge funds because of how such balances are classified toward banks' capital reserves under new regulations. . . Hedge fund managers are beginning to explore non-traditional financing sources outside of prime brokers. Thirteen percent of respondents are seeking or plan to seek financing from non-traditional sources in the next two years, from sources

\footnotetext{
${ }^{10}$ For example, see Hull and White (2012, 2014a, 2014b), Albanese and Andersen (2014), and Andersen, Duffie, and Song (2016).

${ }^{11}$ See http://www.ey.com/gl/en/newsroom/news-releases/news-ey-hedge-fundsconfront-impact-of-financial-market-regulations-and-challenges-of-evolvingprime-broker-relationships.
} 
including institutional investors and sovereign wealth funds, custodians, or other hedge funds.

As another example, a recent article from the Institute and Faculty of Actuaries argues that new regulations have the potential to impose indirect costs on pension funds: ${ }^{12}$

As a result, pension funds could be forced into using central clearing which, Mercer said, requires a number of operational changes. Schemes are yet to make due to the expectation they will be exempt from it for three years. Ben Gunnee, European director of Mercers Sentinel group, said: 'Those schemes that try to undertake hedging strategies using interest rate swaps outside central clearing may find the cost prohibitively expensive under the new regulations. The additional capital charges levied on counterparties will ultimately result in trading costs increasing for pension funds wishing to hedge liabilities through swaps.'

\section{TREASURY NOTES AND TREASURY NOTE FUTURES}

In this study, we focus on the direct funding costs and balance sheet costs associated with Treasury securities. A key advantage of this approach is that there are liquid futures markets for taking synthetic positions in Treasury notes and bonds as well as an active repo market for financing Treasuries. Thus, we can directly observe the direct funding costs for Treasuries in the repo market and solve for the implied funding rate from futures prices.

We focus on five-year Treasury notes and Treasury note futures in the analysis since they were among the most actively-traded Treasury securities and futures contracts during the sample period. For example, Brandt, Kavajecz, and Underwood (2007) and Mizrach and Neely (2006) find that price discovery in the Treasury futures market is most efficient for the five-year Treasury note futures contract. Furthermore, the design of the Chicago Mercantile Exchange's (CME) five-year Treasury note futures contract has the important advantage of minimizing the value of the timing and cheapest-to-deliver options implicit in Treasury futures contracts. For example, only a very narrow range of maturities is deliverable into the contract, making the possibility of a switch in the cheapestto-deliver note far less likely than is the case for other Treasury futures contracts. In this section, we summarize the key frictions and constraints faced by an in-

${ }^{12}$ See http://www.theactuary.com/news/2012/06/basel-iii-could-increase-costof-trades-by-pension-schemes/. 
termediary in taking a direct position in Treasury notes, and contrast these with those associated with a synthetic position via the Treasury note futures market.

\subsection{Treasury Notes}

Financial intermediaries face increased balance sheet constraints when they take a direct ownership position in Treasury securities via the repo market. This is because repo transactions are on-balance-sheet secured loans for accounting and regulatory purposes and thus require incremental regulatory capital. ${ }^{13}$ The appendix provides a detailed discussion of the repo market.

Treasury notes are recorded on balance sheet when acquired. ${ }^{14}$ Under current Basel III and Dodd-Frank provisions, all positions in Treasury securities are subject to capital requirements because they are included in the calculation of a bank's total exposure measure. Specifically, the U.S. SLR requires institutions to hold capital against three percent of total balance sheet exposures, regardless of their risk weighting. The Federal Reserve also imposes an additional two-percent buffer in the form of the eSLR for the largest U.S. banks.

The transaction costs associated with trading Treasury notes are relatively small. Fleming (2003) estimates that the bid-ask spread for five-year Treasury notes is on the order of $0.3932 \mathrm{nds}$, or 1.22 cents per $\$ 100$ notional amount. Similar results are reported in Brandt and Kavajecz (2004) and Engle, Fleming, Ghysels, and Nguyen (2012).

The Federal Reserve Board reports that the median tri-party repo haircut for Treasury securities from 2010 to 2016 is two percent. ${ }^{15}$ Finally, repo transactions are also subject to delivery squeezes when repo volume is large relative to supply, which can result in repo fails. In May 2009, the Treasury Market Practices Group introduced a dynamic fails charge for Treasury securities. ${ }^{16}$ Specifically,

${ }^{13}$ Specifically, Statement of Financing Accounting Standards (SFAS) 125 "Accounting for Transfers and Servicing of Financial Assets and Extinguishment of Liabilities" requires that repo transactions be classified as secured loans, and not as financing transactions.

${ }^{14}$ The specific accounting treatment depends on whether the securities are categorized as trading securities, available-for-sale securities, or held-to-maturity securities. See SFAS 115 at http://www.fasb.org/jsp/FASB/Pronouncement_C/Summ aryPage\&cid $=900000010225$.

${ }^{15}$ For example, see https://www.newyorkfed.org/data-and-statistics/data-visual ization/tri-party-repo/index.html\#interactive/haircut.

${ }^{16}$ See Treasury Market Practices Group, "Treasury Market Practices Group Endorses Several Measures to Address Widespread Settlement Fails," November 12, 
the principal recommendation suggested that "market participants agree that the invoice price ... on any cash or financing transaction that fails to settle on the originally scheduled date be reduced at a fails [charge] rate equal to the greater of a) three percent per annum minus the fed funds target rate ... and b) zero."

\subsection{Treasury Note Futures}

A financial institution that takes a synthetic Treasury position via the futures market faces far lower balance sheet costs than is the case for cash positions. In particular, under U.S. GAAP (FASB 133), Treasury futures are derivative instruments whose notional values are carried off balance sheet, and only their fair values are recorded on balance sheet. Because the initial value of a futures contract is zero, however, the mark-to-market value of daily resettled futures contracts is likely to remain orders of magnitude smaller than the market values of the underlying Treasury securities. The appendix provides a detailed discussion of Treasury note futures contracts.

Prior to Basel III, off-balance-sheet interest rate derivatives such as Treasury futures with maturities less than one year had no capital requirements. Under Basel III, there is only a two-percent risk weight for Treasury futures contracts. Furthermore, since Treasury futures are off-balance-sheet instruments, the twopercent risk weight is multiplied by a credit conversion factor of the derivatives position to arrive at the actual capital charge. This implies that the regulatory capital requirement is not based on the notional position as would be the case for a repo transaction. Thus, the capital requirements for Treasury futures positions are substantially lower than those for cash positions.

An important feature of Treasury note futures is that they are virtually free of counterparty credit risk. This is because Treasury note futures contracts are centrally cleared by the CME Clearing Corporation which acts as the counterparty to every trade. By serving as the counterparty to every transaction, the CME becomes the buyer to every seller and the seller to every buyer, essentially eliminating any counterparty credit risk in Treasury notes futures positions.

The transaction costs of trading Treasury note futures contracts are similar to those of the underlying Treasury notes. For example, Holder and Sinha (2009) estimate that the bid-ask spread for Treasury note futures is on the order of 1.7 cents per $\$ 100$ notional position. This is consistent with the estimates in Fleming and Sarkar (1999) and Fett and Hayes (2017).

Treasury note futures contracts are also subject to margining provisions. Participants in the Treasury note futures market post initial margin when a

2008, available at http://www.newyorkfed.org/tmpg/PR081112.pdf. 
transaction is executed and must post additional margin when the balance in the margin account falls below the maintenance margin. The required initial and maintenance margins are adjusted periodically by the CME. During the sample period, the initial margin requirement ranged from 0.54 percent to 1.59 percent of the total notional size of the contract, and averaged 1.03 percent. Thus, the margin requirements for Treasury note futures appear to be generally lower than those in the tri-party Treasury repo market.

In summary, the transaction costs and margin requirements for Treasury notes and Treasury note futures are roughly similar in magnitude. Thus, their net effect on estimates of balance sheet costs is likely to be close to a wash. By contrast, there are major differences in the capital constraints and requirements imposed on Treasury note cash and futures positions. These considerations strongly support the notion that balance sheet costs are measurable by the difference between the implied repo rate and the actual repo rate.

\section{THE DATA}

In this section, we briefly describe the data sets and variables used in the study. Table A1 of the appendix provides detailed information about the data and the data sources.

We collect data for five-year Treasury note futures prices, trading volume, open interest, and margins from the Bloomberg system. Overall, we have data for the 103 futures contracts with quarterly expirations in the June 1991 to December 2016 sample period. For each futures contract, we also identify the set of deliverable Treasury notes and collect information about their coupon rates, maturity dates, conversion factors, and prices from the Bloomberg system. Table 2 presents summary statistics for the Treasury note futures contracts. To value the cheapest-to-deliver option, we also collect data on interest rate swap rates as well as cap, floor, and swaption volatilities from quote sheets from the broker Tradition Inc. for the first few years of the sample period, and then from the Bloomberg system for the remainder of the sample period.

We obtain data for general collateral Treasury repo rates for overnight, 1week, 2-week, 3-week, 1-month, 2-month, 3-month, 4-month, 5-month, and 6month horizons from the Bloomberg system. The repo rates are interpolated to match exactly the maturity implied by the date on which delivery into the corresponding futures contract occurs. Not all term repo rates are available continuously throughout the sample period, in which case we use the closest available tenor as the repo rate. 
Finally, we collect data on a set of financial market variables including prices, spreads, and outstanding notional amounts from a number of sources. Furthermore, we also collect balance sheet and capital ratio information for U.S. financial institutions.

\section{MEASURING BALANCE SHEET COSTS}

The balance sheet costs are estimated using a simple two-step procedure. In the first step, we estimate the funding rate implicit in the five-year Treasury note futures contract - designated as the implied repo rate. In the second step, we subtract the actual repo rate for financing five-year Treasury notes from the implied repo rate. The appendix provides the full details on this methodology.

To illustrate how the implied repo rate is computed, consider the simple case where the currently cheapest-to-deliver note eligible for delivery into the futures contract does not pay any coupons between now and the expiration date of the contract. ${ }^{17}$ In this situation, the implied repo rate $I R$ is given by

$$
I R=\frac{F-P}{P} \times \frac{360}{N}
$$

where $F$ is the futures price for the cheapest-to-deliver note and $P$ denotes the current market price of that note. The futures price $F$ is obtained by making a small adjustment to the market futures price to back out the value of the cheapest-to-deliver option the contract confers on the seller. The appendix describes the closed-form algorithm used to solve for the value of this option. In general, the value of the option is very small due to the high correlation among the notes that are eligible for delivery into the five-year Treasury note futures contract.

Figure 1 plots the time series of implied repo rates and repo rates during the sample period. As shown, both implied repo rates and repo rates vary significantly over time, with both taking their highest values during the 1990s, and their lowest values during the post-2008 financial crisis period. Despite the wide range of variation, however, Figure 1 shows that the implied repo rate is generally higher than the repo rate throughout most of the sample period. This implies that balance sheet costs exist throughout the sample and not just as a result of

\footnotetext{
${ }^{17}$ The cheapest-to-deliver note is the note with highest implied repo rate among all notes eligible for delivery into the note futures contract. See Burghardt and Belton (2005) and Choudhry (2006).
} 
post-crisis financial regulation.

Table 3 presents summary statistics for the estimated balance sheet costs which are computed as the difference between the implied repo rate and the repo rate with the same horizon. The results show that the balance sheet costs are predominantly positive throughout the sample period and are significant from both a statistical and economic perspective. In particular, the average value of the balance sheet costs during the entire sample period is 81.05 basis points. This average value is highly statistically significant. Furthermore, the average value of the balance sheet costs is positive for 23 of the 26 years in the sample period. Overall, 82.68 percent of the balance sheet cost estimates are positive. For 16 of the 26 years in the sample period, the percentage of positive balance sheet estimates is greater than 90 percent, including five years in which 100.00 percent of the estimates are positive. On the other hand, a few years have relatively small percentages of positive estimates, including years in which only 10 to 20 percent of the estimates are positive.

These results have many important implications for financial markets. In particular, they suggest that the cumulative effect of balance sheet constraints effectively adds 81 basis points to the cost of capital of financial intermediaries. To put these costs into perspective, we observe that the average term repo rate during the sample period is 281 basis. Similarly, the cost of funding earning assets for all U.S. banks as reported by the FDIC averages 256 basis during the same period. Thus, the incremental shadow funding costs imposed by balance sheet constraints are on the order of 30 percent of the total direct funding costs faced by U.S. financial intermediaries. Far from being a minor friction, balance sheet costs of this magnitude clearly have the potential to be of first-order importance in their effects on financial intermediaries and on asset pricing.

Figure 2 plots the time series of balance sheet costs throughout the sample period. The plot confirms that the balance sheet costs are predominantly positive. As shown, however, there is significant time series variation in their values. The balance sheet costs typically lie in the range of zero to 200 basis points, but there are clearly periods during which their values are higher or lower. Figure 2 also shows that many of the largest values appear to coincide with major disruptive events in the financial markets. For example, balance sheet costs spike during the Mexican Debt Crisis, the Asian Financial Crisis, the Long-Term Capital Management Crisis, the 2008 Financial Crisis, and the European Sovereign Debt Crisis. In contrast, the period from January 1999 to April 2002 is particularly noteworthy since the average value of the balance sheet costs is slightly negative during this period. 


\section{THE IMPACT OF CAPITAL CONSTRAINTS}

In this section, we explore the relation between the estimated balance sheet costs and the capital constraints faced by financial intermediaries. We first examine whether the balance sheet costs reflect the cost of debt and equity capital of financial institutions. We then examine whether the balance sheet costs are related to the amount of capital that financial institutions are constrained to hold.

\subsection{The Cost of Capital}

If financial institutions shift their capital structures towards longer-term financing and/or higher levels of equity as a result of tighter balance sheet constraints, then we would expect that balance sheet costs should reflect the costs of these sources of funds. To provide a specific example, consider the case of a brokerdealer that holds Treasury bonds in inventory. Even if most of the Treasury bond position is financed using a secured repo loan, the broker-dealer may require additional capital because of the haircut on the repo loan and Basel III supplementary leverage ratio requirements. To the extent that the cost of this additional capital exceeds the cost of secured repo financing, the financial institution will view the incremental expense as a balance sheet cost. To explore this, we regress the balance sheet costs on various measures of the cost of debt and equity capital for financial institutions.

As proxies for the cost of equity, we use the average earnings/price ratio and the dividend yield for the banks in the banking industry portfolio defined by the Fama-French 49 industry classification. To reflect the possibility that regulatory capital and liquidity requirements may require financial institutions to reduce debt rollover risk by using more stable longer-term borrowing, we also include the slope of the term structure as measured by the difference between the ten-year and three-month Treasury rates. To capture the credit dimension of the cost of a financial institution's capital, we include several credit spread measures. The first is a measure of the marginal funding cost for financial assets faced by banks. This measure is computed as the quarter-over-quarter change in the average funding cost for earning assets of all banks reported by the FDIC. ${ }^{18}$ By including the change in the average, this measure reflects the incremental funding costs that a bank would face in acquiring new financial assets. The second is the spread between three-month Libor and three-month Treasury rates. This important spread - known as the TED spread - reflects the incremental cost

\footnotetext{
${ }^{18}$ The funding cost for earning assets is defined as total interest expense paid on deposits and other borrowed money as a percentage of average earning assets. See https://www.fdic.gov/bank/ analytical/qbp/glossary.html.
} 
faced by banks that borrow short-term funds in the Libor market. The third is the ten-year swap spread which reflects the longer-term incremental funding costs for financial institutions relative to Treasury borrowing costs. Table A1 of the appendix describes each of the variables and the associated data sources.

Some of the time variation in balance sheet costs could also be due to seasonality in the way that financial information is reported. In particular, financial information is typically reported to regulators on a quarterly cycle (for example in quarterly call reports). Other disclosures occur on an annual cycle. Thus, compliance with capital requirements and other regulatory constraints may be assessed on a periodic basis as financial information is made public. In addition, there is an extensive literature discussing the incentives firms may have to engage in the practice of "window dressing" in which they may improve the appearance of their balance sheets by temporarily reducing their holdings of securities or their leverage for key reporting dates. ${ }^{19}$ In that case, balance sheet constraints could be less binding at some times than others. We control for this possibility in the regression by including quarter-end dummy variables.

We begin by first computing monthly averages of the balance sheet costs throughout the sample period. We then regress these monthly measures of balance sheet costs on the cost of capital variables described above as well as on dummy variables that take a value of one for the months of March, June, September, and December that mark the end of the quarter or year, and zero otherwise. We also include the lagged values of the balance sheet cost measure as a control for time series dependence in the dependent variable of the regression.

Table 4 reports the results from the regression. The results provide strong support for the hypothesis that there are seasonal effects in balance sheet costs. In particular, the coefficient for the December dummy variable is significantly negative. The value of the coefficient indicates that the balance sheet costs are roughly 44 basis points lower at year end than during other months. Intuitively, this result makes sense since if security broker-dealers engage in year-end window dressing, then they may actually be less financially constrained during December. In turn, this implies that their marginal balance sheet costs could be lower in December, consistent with these empirical results. Similarly, the coefficient for the September quarter-end dummy variable is significantly negative (at the tenpercent level).

The regression results also provide strong support for the hypothesis that the estimated balance sheet costs reflect the cost of debt and equity capital for financial institutions. The coefficient for the earnings/price measure is positive

${ }^{19}$ For example, see Griffith and Winters (1997), Copeland, Martin, and Walker (2014), Owens and $\mathrm{Wu}$ (2014), and Munyan (2015). 
and statistically significant. The positive sign of this coefficient suggests that balance sheets costs increase directly with the required rate of return on equity capital. This result is not only very intuitive, but is also fully consistent with the interpretation that regulatory capital requirements impose significant costs on financial institutions that carry over into their implicit financing terms.

The coefficient for the slope of the term structure is also positive and significant, indicating that balance sheet costs increase as it becomes more costly to borrow longer-term funds. Similarly, the coefficient for the marginal funding costs for earning assets is positive and significant. Finally, the coefficient for the Libor-Treasury spread is positive, but is only significant at the ten-percent level. Together, these results provide strong evidence that balance sheet costs increase as the cost of debt capital increases. This is again intuitive and consistent with the hypothesis that regulatory capital requirements are costly and reflected in implicit borrowing rates.

Finally, the monthly balance sheet cost measures display a significant degree of persistence over time. In particular, the coefficient on the lagged balance sheet cost measure is 0.5534 and highly significant.

\subsection{Capital Requirements}

The previous section showed that the cost of capital is correlated with balance sheet costs. In this section, we explore the closely-related issue of how balance sheet costs are related to the capital held by financial intermediaries. In particular, we focus on the relation between estimated balance sheet costs and the key capital and equity ratios that play central roles in the current Basel III regulatory environment. Even though we focus on this set of ratios, however, it is important to observe that regulatory capital requirements are present throughout the entire sample period - not just since the Basel III framework was adopted. In particular, Tier 1 capital ratio and total capital ratio requirements were implemented with Basel I in the early 1990s, and the Federal Deposit Insurance Corporation Act (FDICA) from December 1991 included leverage restrictions. A three percent leverage ratio was part of the Basel II capital rules from the early 2000s. The timeline in Table 1 illustrates that financial institutions have continuously faced varying types of capital requirements during the sample period. Furthermore, financial institutions that appear too leveraged are always at risk for downgrades by credit rating agencies or may face higher margin requirements and haircuts from their counterparties. Thus, financial institutions face both explicit and implicit capital requirements.

Intuitively, it is clear that an increase in the amount of capital held by a financial institution should be directly related to their balance sheet costs. This follows since increases in capital ratios are likely driven primarily by tighter 
regulatory capital requirements. The tighter the requirements, the higher is the marginal balance sheet cost of acquiring additional financial assets. Thus, we would expect to see a positive relation between capital ratios and balance sheet costs.

We include five key capital and equity ratios in our first regression analysis. Specifically, we select capital ratios based on Tier 1 capital, total capital, and equity capital because these variables were key components of capital regulation starting with the Basel I framework and the FDICA in the early 1990s, almost two decades before the set of rules introduced in the wake of the financial crisis. The first is the Tier 1 Capital Ratio which is defined as total Tier 1 capital as a percentage of total risk-weighted assets. The second is the Core Capital Ratio which is defined as total Tier 1 capital as a percentage of average total assets minus ineligible intangibles. The third is the Equity Ratio which is defined as total equity capital as a percentage of total assets. Fourth, the Total Capital Ratio is defined as total risk-based capital as a percentage of risk-weighted assets. The fifth is total equity of broker-dealers expressed as a percentage of total assets, where we first subtract out all repo positions from the aggregate broker-dealer balance sheet. All of these capital ratios are quarterly averages over all banks or broker-dealers and are obtained from either the FDIC or the Z.1 flow of funds data from the Federal Reserve Board. Table A1 of the appendix provides the definitions and sources of these ratios.

Table 5 reports the results from regressing the balance sheet costs (averaged over the quarter) on the contemporaneous change and first two lagged changes in the individual capital ratios. We focus on changes in order to gauge the effect of marginal changes in capital requirements on balance sheet costs. As before, we include the lagged dependent variable to control for time series effects. We also use fixed effects by quarter of the year to control for potential seasonality. Specifically, we include a dummy variable that takes a value of one for the first quarter, and zero otherwise, a dummy variable that takes a value of one for the second quarter, and zero otherwise, etc. The regression is estimated at a quarterly frequency.

The regression results strongly support the hypothesis that balance sheet costs increase as financial institutions are required to hold additional capital. In particular, the coefficient for the contemporaneous change in the capital ratio is positive and significant in each of the five regressions. Furthermore, the magnitudes of the coefficients are economically significant. For example, an increase in the Tier 1 Capital Ratio of one percentage point (say from five to six percent) translates into an increase of 85.67 basis points in the estimated balance sheet costs over the quarter. 


\section{DO BALANCE SHEET COSTS HAVE REAL EFFECTS?}

In this section, we extend the analysis to examine whether balance sheet costs have real effects on financial intermediaries. In particular, we study whether balance sheet costs affect the asset holding and leverage decisions of financial intermediaries.

Intuitively, we would expect that as it becomes more expensive for financial institutions to own Treasury securities on their balance sheet, they would reduce their holdings of Treasuries. To examine this hypothesis, we collect data on the aggregate Treasury bond holdings of broker-dealers using the flow of funds data of the Federal Reserve Board.

The effect of an increase in balance sheet costs, however, might not be limited simply to holdings of Treasury securities. A financial intermediary might also find it optimal to limit the size of its balance sheet by either selling assets or restricting future asset growth. Alternatively, the financial intermediary could also choose to limit the size of its balance sheet by reducing its leverage. As described by Brunnermeier and Pedersen (2009) and Adrien and Shin (2010), the deleveraging of institutional balance sheets played a major part in the aftermath of the 2008 financial crisis. To explore these effects, we also collect data on the growth rates of assets and leverage ratios of broker-dealers using the flow of funds data of the Federal Reserve Board.

Since prices and quantities are determined jointly in equilibrium, it is important to specify the regression in a way that mitigates the potential effects of endogeneity on the results. Accordingly, we examine whether changes in balance sheet costs are associated with subsequent (rather than contemporaneous) changes in the broker-dealer variables. Specifically, we regress changes in each of the broker-dealer variables on the first three lagged changes in that variable and on the first three lagged changes in the balance sheet costs. As in previous regressions, we also include quarter-of-the-year fixed effects.

Table 6 reports the regression results. As shown, the results provide strong evidence that balance sheet costs have real effects on financial intermediaries. In particular, even after controlling for lagged changes in the dependent variables, the lagged changes in the balance sheet costs have significant predictive power for all three of the broker-dealer measures.

Focusing first on the Treasury holdings regression, Table 6 shows that the coefficient for the first lagged change in balance sheet costs is negative and highly significant, while the second lagged change is also negative and significant (at the ten-percent level). Thus, an increase in balance sheet costs is followed by a signif- 
icant decline in Treasury holdings. This intuitive result suggests that changes in balance sheet costs directly impact the investment decisions and market-making activities of financial intermediaries.

Turning next to the asset growth rate regression, the results indicate that the second lagged change in balance sheet costs has significant predictive power for the asset growth rates of broker-dealers. In particular, the negative sign of the coefficient implies that an increase in balance sheet costs is associated with a significant decline in subsequent asset growth rates. Again, these results are intuitive and consistent with financial intermediaries reducing investment activities in the face of rising balance sheet costs.

Finally, Table 6 shows that increases in balance sheet costs are associated with declines in broker-dealer leverage. Specifically, the coefficient for the second lagged change in balance sheet costs is negative and significant, while the third lagged change is negative and significant (at the ten-percent level). Thus, these results are consistent with a scenario in which financial intermediaries respond to increases in balance sheet costs by deleveraging their balance sheets.

Finding that balance sheet costs have real effects on financial intermediaries has many important implications for asset pricing and markets. For example, if an increase in balance sheet costs results in market makers holding fewer Treasuries in inventory, then the liquidity of the Treasury market could suffer. This is consistent with Duffie (2017) who argues that increases in the capital requirements of bank-affiliated dealers have drained liquidity from over-the-counter markets, especially for products that occupy a lot of space on dealer balance sheets such as bonds and repo. Similarly, finding that financial institutions reduce asset growth and/or deleverage when balance sheet costs increase suggests that these costs could directly impact the willingness of financial intermediaries to make new loans or extend credit. For example, from a recent article by Marlin $(2017):^{20}$

Earlier this year, a large international bank reluctantly jettisoned one of its US lending portfolios. The loans were perfectly healthy and would have remained on the firms books were it not for the capital they required under the US Federal Reserves Comprehensive Capital Analysis and Review (CCAR).

As discussed by Schularick and Taylor (2012) and others, the historical evidence points to a link between credit availability and business fluctuations.

\footnotetext{
${ }^{20}$ See https://www.risk.net/risk-management/5311911/in-a-bind-how-ccar-con strains-us-bank-strategy.
} 


\section{THE EFFECTS ON DERIVATIVES MARKETS}

Given that the real effects of balance sheet costs on financial intermediaries have important implications for liquidity in the cash markets, a natural next step is to explore the effects that balance sheet costs may have on derivatives markets. In this section, we examine the relation between balance sheet costs and the demand for two types of derivatives that allow investors to take synthetic positions in bonds - interest rate swaps and Treasury note futures.

In principle, an increase in balance sheet costs could have multiple effects on the derivatives market. Intuitively, if a financial intermediary were to face an increase in its balance sheet costs, the intermediary could have short-term incentives to swap out of cash positions into synthetic derivative positions, potentially resulting in a temporary increase in the demand for derivatives. In equilibrium, however, the implicit rental rate in derivatives should reflect the increase in balance sheet costs. Thus, the long-term effect of an increase in balance sheet costs could be to reduce the demand for both cash instruments and derivative contracts as financial institutions reduce their risk positions.

We focus first on the effects of balance sheet costs on the demand for interest rate swaps. Specifically, we collect data on the total notional amount of interest rate swaps of all U.S. banks from the Federal Reserve flow of funds data. We then regress the quarterly growth rate in the total notional amount on its first three lagged values and on the contemporaneous and first three lagged changes in balance sheet costs. As before, we include fixed effects for quarters.

Table 7 reports the regression results. As shown, the coefficient for the contemporaneous change in balance sheet costs is positive and significant at the ten-percent level. The coefficient for the first lagged change in balance sheet costs is also positive and highly significant. These results are consistent with the notion that an increase in balance sheet costs may provide financial institutions with short-term incentives to substitute derivatives for cash positions.

In contrast, the coefficient for the third lagged change in balance sheet costs is negative and significant at the ten-percent level. This result, in conjunction with the results in the previous section about the effects on the Treasury holdings of broker-dealers, provides support for the view that increases in balance sheet costs may induce financial institutions to scale back their risk-taking activities. This clearly has major implications not only for financial markets, but also for monetary policy authorities and regulators.

We turn next to the relation between balance sheet costs and the use of Treasury futures contracts. Specifically, we explore the effects of an increase in 
balance sheet costs on the open interest in the Treasury note futures market. We focus on open interest rather than trading volume since open interest reflects overnight positions that are subject to clearing and margin restrictions. In contrast, trading volume may include intraday positions that are closed out rapidly without carrying costs.

In particular, we regress changes in open interest on its own lagged values, and contemporaneous and lagged changes in trading volume, average initial margin requirements, and changes in balance sheet costs. We also include monthof-the-year fixed effects (a dummy variable that takes a value of one in January, and zero otherwise, a dummy variable that takes a value of one for February, and zero otherwise, etc.). The regression is estimated at a monthly frequency.

Table 8 reports the regression results. As indicated, there is a significant positive relation between open interest and lagged trading volume. This makes sense of course since trading activity is a prerequisite for increased open interest. The results for the relation between open interest of Treasury note futures and balance sheet costs closely parallel those for interest rate swaps. In particular, the coefficient for the contemporaneous change in the balance sheet costs is positive and significant at the ten-percent level. By contrast, the coefficient for the second lagged change in balance sheet costs is negative and significant. This mirrors the notion that an increase in balance sheet costs is associated with a short-term increase in demand for synthetic positions, but also results in a decline in longterm demand for risk positions.

\section{COMMONALITIES ACROSS MARKETS}

In previous sections, we have shown that balance sheet costs create a wedge between the funding costs implicit in Treasury note futures and the direct financing costs of Treasury notes in cash markets. An important question is if similar effects could be present in other markets in which these intermediaries participate, when financial intermediaries face tight capital constraints.

One important market in which fixed income broker-dealers are likely to trade is the interest rate swap market. As of the end of 2016, the Bank for International Settlements reports that the total notional size of interest rate swap contracts outstanding was in excess of $\$ 275$ billion. As discussed earlier, receiving fixed in an interest rate swap can be viewed as a synthetic position in a fixed rate bond, while paying fixed in a swap is the equivalent of a short position. Thus, abstracting from Libor and swap counterparty credit risk issues, the spread between swap rates and Treasury yields - known as the swap spread - may also reflect the impact of the balance sheet costs faced by intermediaries in the fixed 
income markets (see Klingler and Sundaresan (2016) and Jermann (2016)).

To explore this, we collect data on swap spreads from the Bloomberg system. We then regress changes in swap spreads for maturities ranging from 5 to 30 years on their lagged values, and on the contemporaneous and lagged changes in the two-year swap spread and balance sheet costs. We include the lagged values of the dependent variable to control for potential time series effects and changes in the two-year swap spread to control for the possibility that variation in swap spreads includes a common liquidity component. ${ }^{21}$

Table 9 reports the regression results. As shown, even after controlling for potential time series and liquidity effects, the coefficient for the first or second lagged change in the balance sheet costs is positive and statistically significant for all maturities (the only exception is the five-year swap spread regression in which the coefficient for the second lagged change in balance sheet costs is positive, but just short of significance at the ten-percent level).

These results provide support for the hypothesis that balance sheet costs may affect funding spreads between synthetic and cash positions in multiple markets. In particular, these results suggest that variation in balance sheet costs has predictive power for subsequent changes in swap spreads. Furthermore, the positive sign of the significant coefficients is consistent with increases in balance sheet costs leading to higher spreads between the funding costs of derivative and cash markets.

It is important to acknowledge, however, that these results are limited in scope. In particular, it is clear from the relatively low adjusted $R^{2} \mathrm{~s}$ of the regressions that swap spreads are driven by factors other than the funding spread between Treasury notes and Treasury note futures. Thus, the spread between the funding costs in the Treasury note and Treasury note futures markets may not provide a full explanation for all differences between cash and derivatives markets. On the other hand, market participants are increasing concerned about spillovers from the repo market to the swap market. For example, from a recent article by Wood (2017): ${ }^{22}$

The future health of over-the-counter derivatives trading is increasingly dependent on the ailing repo market, buy-and sell-side participants have warned. Ties between the two markets are not new, but the growing

${ }^{21}$ For example, Liu, Longstaff, and Mandell (2006) find a significant liquidity component in swap spreads for horizons beyond a few years.

${ }^{22}$ See https://www.risk.net/derivatives/5263741/swaps-markets-health-seen-asresting-on-sickly-repo. 
need for collateral to support both cleared and non-cleared OTC trading means swaps market participants are more reliant on the ability both to exchange cash and securities via repo and to continue rolling those repo transactions over-roughly $70 \%$ of the 2.2 trillion dollar US repo market.

Nonetheless, these results indicate that the funding costs associated with balance sheet constraints may provide at least a partial explanation for asset pricing anomalies that are difficult to reconcile with standard asset pricing theory such as the pricing differences between CDS contracts and corporate bonds (Duffie (2010)), deviations from covered interest rate parity (Brunnermeier, Nagel, and Pedersen (2008), Du, Tepper, and Verdelhan (2017)), the relative pricing of inflation swaps and Treasury Inflation Protected Securities or TIPS (Fleckenstein, Longstaff, and Lustig (2014)), or violations of the martingale property in stock index options (Longstaff (1995)).

\section{CONCLUSION}

Recent theory argues that the funding frictions and capital constraints faced by financial intermediaries not only create limits to arbitrage, but may also have major asset pricing implications through their effects on stochastic discount factors. To date, however, it has proven difficult to quantify the impact of these balance sheet constraints on the funding costs of financial intermediaries.

We propose a novel new measure of these balance sheet or shadow funding costs that is based on the implicit cost of renting intermediary balance sheet space. Specifically, we estimate balance sheet costs using the implied repo rate in Treasury note futures and the term repo rate for financing cash Treasury note positions. The difference between these on- and off-balance-sheet financing rates provides a direct measure of the shadow costs of balance sheet constraints.

We find that these indirect balance sheet costs are significant relative to the direct funding costs of financial institutions. On average, balance sheet costs add 81 basis points to the effective cost of capital of financial intermediaries. We verify that our measure of balance sheet costs is related to the cost of debt and equity of financial intermediaries. We find that increases in balance sheet costs are associated with declines in banks' holdings of Treasury securities as well as with declines in their leverage and asset growth rates. These results strongly support the view that balance sheet constraints can have major effects on market liquidity and on risk-taking by financial institutions which, in turn, may have important implications for the macroeconomy. 
The results also have implications for derivatives markets. Balance sheet costs create a wedge between the funding costs of on- and off-balance-sheet investments. Thus, balance sheet costs have the potential to help resolve a number of perplexing asset pricing puzzles involving the relative pricing of cash market securities and their derivative market counterparts.

Finally, having a direct measure of the impact of capital constraints and regulatory requirements on financial institutions provides a simple way for monetary policy authorities, regulators, and other market participants to assess the impact of these constraints on financial markets and the economy. Our results suggest that these impacts can be large, but also vary significantly through time. 


\section{APPENDIX}

\section{A.1 Data Sources}

Table A1 provides a description of all the data and variables used in the study along with their definitions and corresponding sources for the data.

\section{A.2 The Impact of Direct and Synthetic Positions on SLR and LCR}

Tables A2 and A3 present illustrative examples of the differential impact on an institution's balance sheet and SLR and LCR ratios resulting from taking direct vs. synthetic positions in Treasury securities.

\section{A.3 The Treasury Note Futures Contract}

U.S. Treasury futures are standardized contracts for the purchase and sale of notes and bonds issued by the U.S. Treasury and are traded on the Chicago Mercantile Exchange (CME).

The markets for Treasury notes and bonds futures are among the largest and most liquid in the world. The contracts were first listed in 1977 with the introduction of the 20-year U.S. Treasury bond futures contract. Over time, other maturities were introduced, with trading in ten-year, five-year, and ultra-long Treasury note and bond futures contracts beginning in 1982, 1988, and 2010, respectively. Since inception, the Treasury note and bond futures market has exhibited significant growth. Average daily trading volume is currently in excess of two million contracts per day, with most trading taking place in five-year and ten-year contracts. The average daily trading volume increased significantly from roughly 20,000 contracts in 1991 to more than 700,000 contracts in 2016. The CME reports that transaction volume (measured as aggregate notional trading volume in the five-year Treasury futures contracts as a percentage of notional trade by primary dealers in the cash market for five-year Treasury notes) exceeded 62 percent at the end of 2015 .

In this study, we use the five-year Treasury note futures contract which requires the seller to deliver a $\$ 100,000$ par amount of a U.S. Treasury note at expiration of the futures contract. The specific notes eligible for delivery into the futures are published by the CME, and consist of Treasury notes with an original maturity of not more than five years and three months and a remaining maturity of not less than four years and two months as of the first day of the delivery month. Futures prices are quoted in points $(\$ 1,000)$ and quarters of $1 / 32$ 
of a point with price increments of one-quarter of one thirty-second $(1 / 32)$ of one point ( $\$ 7.8125$ rounded up to the nearest cent per contract). Listed contract expiration months are the first five consecutive contracts in the March, June, September, and December quarterly cycle. Treasury note futures cease trading on the last business day of the contract expiration month and the last delivery day is the third business day following the last trading day (detailed contract specifications are available at www.cmegroup.com/education/about-us-treasuryfutures-and-options.html).

The pricing of Treasury note and bond futures contracts is complex because the seller has options to choose the timing of delivery as well as which bond to deliver in fulfillment of the contract. The futures seller's options with regard to the time of delivery include the timing option (delivery can occur on any day during the future's expiration month), the wildcard option (intent to deliver can be declared at any time during the day until the bond market closes, rather than only during the shorter trading hours of the futures exchange), and the end-ofmonth option (the futures cease to trade a number of business days before the end of the month, but intent to deliver can occur until the last delivery date). Moreover, the futures seller has the option (cheapest-to-deliver or quality option) to deliver any bond among the bonds eligible for delivery. A large literature analyzes how these options impact the prices of U.S. Treasury note and bond futures contracts. See, for example, Carr (1988), Boyle (1989), Hegde (1989), Hemler (1990), and Ritchken and Sankarasubramanian (1992).

We choose the five-year Treasury note futures contract as opposed to a different Treasury note or bond futures contract for several reasons. First, Brandt, Kavajecz and Underwood (2007) and Mizrach and Neely (2008) find that price discovery in the Treasury futures market is most efficient for the five-year Treasury note futures contract. In particular, Mizrach and Neely find that the contribution of the five-year Treasury note futures contract to intra-day price discovery in the futures and cash markets increases significantly after 1999 and exceeds that of the ten-year contract by 2001. Overall, they show that the 5year Treasury cash note and the 30-year Treasury futures contract are significant drivers of price discovery in the Treasury market. Brandt, Kavajecz, and Underwood study price discovery in the futures and cash Treasury market in response to order flow and find that trades in the two- and five-year notes are significantly related to both cash and futures price movements, whereas the impact of trading in the 10- and 30-year securities is far less pronounced. Second, by choosing the five-year Treasury note futures contract, we are reducing the impact of the end-of-the-month option compared to other contract tenors. That is because the futures seller has fewer days to exercise the end-of-the month option in the case of the five-year futures contract. Specifically, the last trading day for the five-year notes futures contract is the last business day of the delivery 
month, and the last day to declare intent to deliver is the first business day of the next calendar month. In contrast, the 10-year Treasury note futures and the Treasury bond futures contracts cease to trade on the seventh business day before the last business day of the delivery month, and the short can declare intent to deliver until the second business day before the last business day of the delivery month. For details on the specific differences between the Treasury note and bond futures contracts, see "Treasury Futures Delivery Options, Basis Spreads, and Delivery Tails," CME Group, September 2016, available at https://www.cmegroup.com/education/files/treasury-futures-basis-spreads.pdf.

\section{A.4 The Repo Market}

A repo transaction is structured legally as a simultaneous agreement between counterparties to engage in a sale of securities on an initial date, with a repurchase of the securities by the initial seller at a later date. U.S. repo transactions are typically documented with the Securities Industry and Financial Markets Association's (SIFMA) Master Repurchase Agreement and the SIFMA/International Capital Market Association (ICMA) Global Master Repurchase Agreement, but there can also be customized agreements between repo counterparties.

The economic effect of a repo transaction is similar to that of a secured loan. In contrast to a secured loan, however, a repo transaction provides significant protections to creditors from the normal operation of U.S. bankruptcy laws, such as the automatic stay and avoidance provisions (11 U.S.C. paragraphs 362(b)(7) and 546(f)). Consequently, in the event of insolvency, the counterparty holding the securities (the cash lender) may liquidate the securities held, and accelerate or terminate the agreement (11 U.S.C. paragraph 559).

Copeland, Duffie, Martin, and McLaughlin (2012) estimate the outstanding value of repo and reverse repo activity in the U.S. at $\$ 3$ trillion and $\$ 2$ trillion, respectively. Comparable or even higher estimates are provided by Gorton and Metrick (2012), Aitken and Singh (2010), and Baklanova, Copeland, and McCaughrin (2015). Also see Krishnamurthy, Nagel, and Orlov (2014). Dealers' reliance on repo financing peaked in 2007 at 32 percent of total liabilities, and has declined steadily since. Dealers have also extended the tenor and staggered the maturity of their repo funding. While a substantial amount of repo is still financed overnight, there has been a lengthening in the maturity of repo funding, particularly for lower-quality collateral (see Baklanova, Copeland, and McCaughrin). Despite the decline in repo activity by U.S. securities dealers and U.S.- chartered banks, repo continues to be a significant source of financing for U.S.-based foreign bank offices which is partly due to differences in regulation (for example, see Mackenzie Smith (2016)). Between 2008 and 2014, repo and fed funds liabilities of foreign bank offices in the U.S. have increased by over 20 
percent, bringing their reliance on this type of funding to 18 percent of total liabilities as of the end of 2014 (Baklanova, Copeland, and McCaughrin).

A repo trade involves the sale of an asset, with an agreement at the time of sale to "repurchase" the same or an identical asset at a specified date in the future. While legal title to collateral is transferred to the "buyer," the accounting treatment of a repo is as a financing transaction, and bonds given as collateral remain on the repo seller's balance sheet. In particular, the seller is entitled to receive the security's coupon interest. The repo buyer treats the repo transaction as a secured loan.

As a collateralized financing transaction, repos are on-balance-sheet transactions. Repo interest is treated as payment of interest and is taken as a charge on an accrual basis. The regulatory treatment of repo transactions is defined in the Statements of Financial Accounting Standards (SFAS) in the United States. Specifically, in SFAS 125, "Accounting for Transfers and Servicing of Financial Assets and Extinguishments of Liabilities," repo transactions are classified as secured loans (repos to maturity, however, are treated as sales and purchases of the securities under SFAS 125 and not as financing transactions). For tax purposes, the Internal Revenue Service treats the repo seller as the tax owner of the asset which means that the repurchase price differential is taxable interest income to the purchaser and interest expense to the seller, and the reverse applies for coupon interest (referred to as "manufactured dividend") during the term of the repo which is taxable income to the repo seller (Internal Revenue Code, Section 864(e)).

Under Basel I, the capital requirements for off-balance-sheet instruments are significantly lower than under Basel III and Dodd-Frank. For instance, interest-rate derivatives such as forward rate agreements (FRAs) and Treasury bond futures of less than one year's maturity had no capital requirements (see Basel Committee on Banking Supervision, "International Convergence of Capital Measurement and Capital Standards," July, 1988, Annex 3, available at: http://www.bis.org/publ/bcbs04a.pdf).

Repo transactions are treated similarly to secured lending under Basel I and are weighted according to the type of asset and not according to the type of counterparty with whom the transaction has been entered into. Since repo is treated as a secured deposit on the banking book, no counterparty risk exposure need be calculated. Reverse repos (i.e. purchase and resale agreement where the bank is the receiver of the asset) are treated as collateralized loans and risk is measured as an exposure to the counterparty. However, where the asset temporarily acquired is a security which attracts a preferential risk weighting, this would be recognized as collateral and the risk weighting would be reduced accordingly (see Basel Committee on Banking Supervision, "International Convergence of 
Capital Measurement and Capital Standards," July, 1988, Annex 3, footnote 1, available at: http://www.bis.org/publ/bcbs04a.pdf). The implications of Basel II for repo transactions are for the most part minor, because the framework provides for collateralization to reduce credit risk exposure and thus to lower risk based capital requirements. In contrast, the introduction of Basel III, and the SLR in particular, imply substantial changes in terms of their regulatory capital requirements.

\section{A.5 The Basel III Framework}

The Basel III framework, introduced by the Basel Committee in December 2010, redefined regulatory capital, established a global leverage ratio, and increased banks' required risk-weighted capital ratios. In addition to tightening equity and Tier 1 capital requirements, U.S. regulators increased the minimum leverage ratio from three to four percent for all banks (the leverage ratio is measured as Tier 1 capital to average consolidated assets). The supplementary leverage ratio (SLR) was first introduced in June 2012 (finalized in July 2013) and applies to large financial institutions with $\$ 250$ billion or more in total consolidated assets, or $\$ 10$ billion or more in on-balance-sheet foreign exposures. Regulators set the minimum of Tier 1 capital as a percent of total non-risk weighted exposures at three percent. The SLR is calculated as Tier 1 capital divided by total exposures (including some off-balance-sheet assets and derivatives exposures) and total exposures have a risk-weight of one, regardless of whether assets have lower risk weights in calculating risk-based capital ratios. Total exposure is defined as the sum of on-balance-sheet assets; potential future exposure from derivatives; repo-style transactions; and repo exposure when acting as an agent, less any reduction due to netting agreements. Total exposure is typically higher than total on-balance-sheet assets (Allahrakha, Glasserman, and Young (2015) report that for the largest top-Tier U.S. banks, total exposures are 44 percent greater than total assets and 27 percent greater for all large U.S. banks). Netting rules also became more stringent and banks were no longer allowed to net repo activity because short-term wholesale funding transactions were required to be reported on a gross basis, thus greatly reducing balance sheet efficiencies (netting rules apply to qualified activities between banks/dealers).

The SLR faces criticism from a number of large banks as a binding constraint on their use of capital. In particular, the SLR requires that transactions in the triparty repo market be included in the Basel III total exposure measure. This can adversely effect banks' leverage ratios and market participants expressed concern that the SLR could negatively impact dealers' participation in the triparty repo market, a low margin business, where dealers and banks fund asset positions from market making (Baklanova, Copeland and McCaughrin (2015)). Copeland 
et al. $(2012,2014)$ estimate that the estimated average share of triparty repo activity attributed to primary dealers has declined from 90 percent to 80 percent since 2012.

In addition to the SLR, U.S. regulators introduced the Enhanced Supplementary Leverage Ratio (eSLR) as an additional component in determining regulatory capital requirements. The eSLR, introduced in July 2013, increased the capital buffer above the three percent supplementary leverage ratio to a minimum of five percent of Tier 1 capital divided by total exposures for a covered bank holding company. In addition, any insured depository institution that is a subsidiary must maintain a minimum of six percent to pay out unrestricted bonuses and dividends. The eSLR applies only to the largest, most complex U.S. bank holding companies, those with assets of at least $\$ 700$ billion or with assets in custody of at least $\$ 10$ trillion on a consolidated basis with their insured banking subsidiaries. As of 2016, eight U.S. bank holding companies fit this description. These same banks have been identified by the Basel Committee as G-SIBs (the G-SIBs as of November 2016 are published by the Financial Stability Board and are available at http://www.fsb.org/wp-content/uploads/2016-list-ofglobal-systemically-important-banks-G-SIBs.pdf).

In addition to stricter leverage ratio requirements, Basel III introduced the liquidity coverage ratio (LCR) and the net stable funding ratio (NSFR). The liquidity coverage ratio requires a banking organization to hold unencumbered high-quality liquid assets that exceed its expected net cash outflows over a 30day stress period. Covered bank holding companies' ratios must be equal to or greater than one and cash outflows include repo activities of broker-dealer subsidiaries. To qualify as high-quality liquid assets, assets must meet certain operational requirements including that the assets be unencumbered and under the control of the treasury function (Section 22, p. 61530 of the U.S. final rule implementing the LCR, available at www.gpo.gov/fdsys/pkg/FR-2014-1010/pdf/2014-22520.pdf). In particular, this requirement implies that the assets cannot be financed in repo and must be available to the bank's treasury function to liquidate. The liquidity coverage ratio uses the same outflow rates to secured funding transactions and haircuts to collateral. When a bank holding company funds securities via repo, only outflows associated with the secured funding are used in determining the LCR as the collateral would not meet the operational requirements of high-quality liquid assets. Through this mechanism, repos can negatively impact the LCR and bank holding companies may choose to move away from repo transactions to fund less liquid high-quality asset positions. Allahrakha, Cetina and Munyan (2016) document using data on tri-party repos that following the 2012 introduction of the supplementary leverage ratio, brokerdealers affiliated with bank holding companies decreased their repo borrowing but increased their use of repo backed by more price-volatile collateral. In ad- 
dition to the LCR, the Basel III framework implemented the net stable funding ratio which is a measure of a bank's liquidity needs over a one-year horizon. The NSFR matters for repo financing because U.S. bank holding company-affiliated dealers that lend cash and receive collateral in the repo, are required to set aside stable funding in the amount of ten percent of the repo loan to meet net stable funding requirements.

\section{A.6 Computing the Balance Sheet Cost Measure}

The balance sheet cost measure is computed as the difference between the implied repo rate implicit in the five-year Treasury note futures contract and the corresponding term repo rate for the underlying Treasury notes. To provide greater clarity, we will distinguish between the implied repo rate for the futures contract and the implied financing rates for individual securities. Note, however, that what we term implied financing rates are often referred to as implied repo rates by practitioners.

To solve for the implied repo rate, we use a multistep procedure. First, we compute implied financing rates for each of the deliverable notes. Second, we use these implied financing rates to identify the cheapest-to-deliver note. Third, given this identification, we solve for the value of the cheapest-to-deliver option embedded in the Treasury note futures contract. Finally, we adjust the market futures price by the value of this option to obtain the futures price $F$ and then solve for the implied repo rate $I R$.

Implied financing rates can be calculated for each day and for each note eligible for delivery into the futures contract. Let the current (time- $t$ ) price of the $i$-th deliverable Treasury note be $P_{i}$, where $i=1, \ldots, K$ denotes the $i$-th note among the set of $K$ notes that are eligible for delivery. For the present, we focus on a specific deliverable Treasury note and omit subscripts except when needed for clarity. Let $I$ denote the price to be paid for the note at the time of its delivery in $N$ days (designated the invoice price), and denote the current Treasury note price (clean price at settlement time) simply as $P$. Let $I F$ denote the implied financing rate associated with the delivery of the note in $N$ days. The implied financing rate is given by

$$
I F=\frac{I-P}{P} \times \frac{360}{N}
$$

The first eligible delivery day for the five-year Treasury note futures is the first business day of the contract delivery month. The short can declare intent to deliver starting from the second business day before the first business day of an expiring contract's delivery month. The last trading day for the futures contract is the last business day of the delivery month. The short must declare intent to 
deliver by the first business day of the calendar month following the contract's delivery month. The last delivery day is the third business day of the following calendar month.

If the deliverable Treasury note pays a coupon between trade settlement and the delivery date, its implied financing rate is adjusted for coupon reinvestment income. Standard practice is to assume that intermediate coupons are reinvested at the implied financing rate, the note's yield-to-maturity, or at the overnight repo rate and rolled over. We adopt the first convention where the notes' semi-annual coupon $C / 2$ is reinvested at the implied financing rate. Let $N$ again denote the number of days from settlement to delivery and let $N^{\prime}$ be the number of days between the intermediate coupon payment and the delivery date. The implied financing rate adjusted for the interim coupon is

$$
I F=\frac{I+C / 2-P}{(P \times N)-\left(C / 2 \times N^{\prime}\right)} \times 360
$$

where $C / 2$ is the semi-annual coupon of the note (see Choudhry (2006), p. 25).

The Treasury note $i \in\{1, \ldots, K\}$ with the highest implied financing rate among the notes eligible for delivery into the futures contract is designated cheapest-to-deliver (CTD) because it is the cheapest note to deliver into the futures contract in terms of its carrying costs. The CTD can change over time if there are changes in relative yield levels of the deliverable notes, if the shape of the yield curve changes, or if specific issues trade on special in the repo market. Benninga and Wiener (1999) show that in many cases, the CTD will be the deliverable note with the highest coupon rate when yields are lower than the five-year Treasury note future's notional coupon of six percent, and that under a flat term structure, the CTD has the shortest maturity of all deliverable notes when yields are lower than the five-year Treasury note future's notional coupon.

The CTD can be delivered on any business day of the delivery month. However, delivery predominantly occurs either on the first day of the delivery month or on the last delivery day of the month (Choudhry (2006) p. 92). As shown by Bowen, Hawryzs, Sturm, and Zangrill (2016), physical delivery occurred only for 2.7 percent of the open interest between March 1991 and December 2015. Given this, we will assume that if the yield on the CTD currently exceeds the implied financing rate, delivery is on the last business day of the month, otherwise, delivery is the first business day of the delivery month. Let $N^{F}$ and $N^{L}$ denote the number of days between the current date and the first and the last business day of the month, respectively. Intuitively, delivery occurs on the last day of the delivery month because the short future earns more by carrying the note than by making delivery and investing the proceeds at money market rates. 
This delivery day convention is widely adopted in the academic literature and allows us to abstract from wild card or timing options (see Kane and Marcus (1986a, 1986b) and Hemler (1990)).

When delivery occurs in $N \in\left\{N^{F}, N^{L}\right\}$ days, we roll the futures contract forward to the next futures maturity, and a new set of notes becomes eligible for delivery. For instance, we roll the March 1995 futures over to the June 1995 contract on March 1, 1995, which is the first day of the delivery month, or first delivery day. At any date prior to delivery, the reference futures contract is the contract closest to expiration, which is designated the first-near futures. Using the first-near contract is a common approach in the literature as this roll methodology excludes futures trading activity in the delivery month which might be affected by settlement induced illiquidity (see Brandt, Kavajecz, and Underwood (2007) and Mizrach and Neely (2008)), as well as the shift in trading activity from the current futures to the next nearby contract month (see Hemler (1990) and Johnston, Kracaw, and McConnell (1991)).

For brevity, we will refer to the implied financing rate of the CTD, as the implied financing rate and use the following algorithm to identify the delivery dates for each contract. On each date $t$ and for each note $i$ in the deliverable basket $i \in\{1, \ldots, K\}$, we calculate the implied financing rate to the first delivery date and the implied financing rate to the last delivery date. If the implied financing rate to the first delivery date exceeds the implied financing rate to the last delivery date, we assume that delivery of note $i$ is on the first business day of the delivery month and set $N=N^{F}$. Alternatively, if the implied financing rate to the first delivery date is less than or equal to the implied financing rate to the last delivery date, we assume that delivery of note $i$ is on the last business day of the delivery month, $N=N^{L}$.

As described above, the deliverable note $i$ from the set of $i=1, \ldots, K$ deliverable notes with the highest implied financing rate is designated the cheapestto-deliver security. Without loss of generality, we index the CTD by $j$ where,

$$
I F_{j}>I F_{i} \quad \forall i \in\{1, \ldots, K\}, \quad i \neq j .
$$

and where $I F_{i}$ is given by Equation (A1), or Equation (A2) if an interim coupon is paid. Next, given the current CTD note and its delivery date in $N \in\left\{N^{F}, N^{L}\right\}$ days, the number of days to delivery of all deliverable notes is set to $N$. In our sample, no designated CTD is delivered on the first delivery date and last delivery is always optimal. Hence, this approach does not affect our results, but it ensures that comparisons of the implied repo rate between eligible-for-delivery notes use the same delivery date. 
Obtaining the invoice price $I$ in Equations (A1) and (A2) is straightforward because the calculation is specified by the exchange. Specifically, the invoice price of a deliverable note can be expressed as

$$
I=M \times C F+A,
$$

where $M$ is the current market futures prices, $C F$ denotes the conversion factor of the deliverable note, and $A$ denotes the accrued coupon on the note from its last coupon payment date to the delivery date in $N$ days. Delivery invoice conversion factors for Treasury futures are published by the exchange. For any Treasury futures contract for a given delivery month, the conversion factors for all deliverable grade securities are determined before the contract is listed for trading, and remain fixed throughout the life of the contract. Note that the notional coupon in the contract specification determines each deliverable note's conversion factor. Accrued interest is calculated using standard Treasury market conventions on the basis of the actual number of days in the semi-annual interval between the date of the last coupon payment preceding delivery and the date of the next coupon payment following delivery. Accrued interest includes any coupon interest that has accrued but has not been paid as of the delivery date. Details on conversion factors and the calculation of the invoice price are provided in Burghardt and Belton (2005) and Kronstein, Lao, Mirza, and Sturm (2016).

As discussed earlier, in addition to the CTD or quality option, a short Treasury note futures position also has a timing option which is the short's right to decide when to deliver during the delivery month. The futures contract confers the right to the short to declare the intent to deliver at the end of the delivery month after the futures contract has ceased trading. From the last trading day through the last delivery date, the futures price used to calculate the invoice price remains fixed at the last settlement price, while the prices of the deliverable issues and financing rates may fluctuate, thus potentially affecting which note is cheapest to deliver. This option is referred to as the end-of-the-month option. The wild-card option refers to the short's privilege to declare intent to deliver on any given day during the delivery month after the daily futures settlement has been fixed, but the cash Treasury market remains open. Prior research suggests that any effect from these timing options is expected to be of secondor third-order importance and that the most significant impact on the futures is due to the CTD option. For an overview of this literature, see Chance and Hemler (1993). In addition, our results indicate that the value of the timing option should be close to zero, because throughout our entire sample there is no case in which early delivery on the first business date of the delivery month is optimal. 
We will make the mild assumptions that the timing option, the wildcard option, and the end-of-month option are negligible. Furthermore, since the time to expiration for all of the futures contracts in the sample is only on the order of months, the difference between futures and forward contracts is easily shown to be negligible. Accordingly, we will also abstract from forward/futures differences.

We index the three notes with the highest individual implied repo rates among the set of deliverable notes by $j, k$, and $l$, where $j$ specifically denotes the index of the note that is currently the CTD note. From Equation (A4), the invoice prices for these notes can be expressed as

$$
I_{i}=M \times C F_{i}+A_{i}, \quad i \in\{j, k, l\} .
$$

Let $\tilde{P}_{i}$, where $i \in\{j, k, l\}$, denote the prices of these bonds at the contract expiration date in $N$ days.

Standard valuation results imply that the current market futures price is given by solving for the implicit value of $M$ that sets the expected cash flow to the short from the futures contract equal to zero (for example, see Cox, Ingersoll, and Ross (1981)),

$$
0=E\left[\max \left(I_{j}-\tilde{P}_{j}, I_{k}-\tilde{P}_{k}, I_{l}-\tilde{P}_{l}\right)\right]
$$

This can be rewritten as,

$$
0=E\left[I_{j}-\tilde{P}_{j}\right]+E\left[\max \left(0, I_{k}-\tilde{P}_{k}-\left(I_{j}-\tilde{P}_{j}\right), I_{l}-\tilde{P}_{l}-\left(I_{j}-\tilde{P}_{j}\right)\right)\right]
$$

The second expectation in this expression represents the value of the cheapest-todeliver or quality option. Let us denote the value of this second expectation by $V$. Substituting in the definition of $I_{j}$, recalling that the expected value of $\tilde{P}_{j}$ under the risk-neutral measure equals the futures price $F$ of the cheapest-to-deliver note (see Cox, Ingersoll, and Ross), and rearranging implies,

$$
F=M \times C F_{j}+A_{j}+V
$$

We model the CTD option as a three-asset exchange option which parallels commonly used approaches in the literature. For example, Gay and Manaster (1984) use a two-asset approximation to value the exchange option in the wheat 
futures market. Hemler (1990) extends Gay and Manaster to more than two deliverable assets and applies the model to price Treasury futures contracts. The value of the CTD option has also been studied by Benninga and Smirlock (1985), Hegde (1989), Boyle (1989), Barnhill (1990), Kane and Marcus (1986a), and Ritchken and Sankarasubramanian (1992). We note that while computations for more than three assets could be done, the results in Hemler (1990) suggest that there is little chance that the cheapest-to-deliver issue will not be among the set of three currently cheapest-to-deliver issues.

Let the random variables $X \equiv I_{k}-\tilde{P}_{k}-\left(I_{j}-\tilde{P}_{j}\right)$ and $Y \equiv I_{l}-\tilde{P}_{l}-\left(I_{j}-\tilde{P}_{j}\right)$ be normally distributed. We denote their means by $\mu_{X}$ and $\mu_{Y}$, their variances by $\sigma_{X}^{2}$ and $\sigma_{Y}^{2}$, and the correlation by $\rho$. Define $Z \equiv \max (X, Y)$. From Equation (A9), we can express $V$ as

$$
\begin{aligned}
V & =E[\max (0, X, Y)], \\
& =E[\max (0, \max (X, Y))], \\
& =E[\max (0, Z)] .
\end{aligned}
$$

From Equations (1) and (2) of Nadarajah and Kotz (2008), the density $f(Z)$ of $Z$ can be expressed as

$$
\begin{aligned}
f(Z)= & \frac{1}{\sigma_{X}} \phi\left(\frac{-Z+\mu_{X}}{\sigma_{X}}\right) \times N\left(\frac{\rho\left(-Z+\mu_{X}\right)}{\sigma_{X} \sqrt{1-\rho^{2}}}-\frac{-Z+\mu_{Y}}{\sigma_{Y} \sqrt{1-\rho^{2}}}\right) \\
& +\frac{1}{\sigma_{Y}} \phi\left(\frac{-Z+\mu_{Y}}{\sigma_{Y}}\right) \times N\left(\frac{\rho\left(-Z+\mu_{Y}\right)}{\sigma_{Y} \sqrt{1-\rho^{2}}}-\frac{-Z+\mu_{X}}{\sigma_{X} \sqrt{1-\rho^{2}}}\right),
\end{aligned}
$$

where $\phi(\cdot)$ and $N(\cdot)$ are, respectively, the probability density function and cumulative distribution function of the standard normal distribution. Thus, the value of $V$ can be determined by straightforward integration,

$$
\begin{aligned}
V= & \int_{0}^{\infty} \frac{1}{\sigma_{X}} \phi\left(\frac{-Z+\mu_{X}}{\sigma_{X}}\right) \times N\left(\frac{\rho\left(-Z+\mu_{X}\right)}{\sigma_{X} \sqrt{1-\rho^{2}}}-\frac{-Z+\mu_{Y}}{\sigma_{Y} \sqrt{1-\rho^{2}}}\right) \\
& +\frac{1}{\sigma_{Y}} \phi\left(\frac{-Z+\mu_{Y}}{\sigma_{Y}}\right) \times N\left(\frac{\rho\left(-Z+\mu_{Y}\right)}{\sigma_{Y} \sqrt{1-\rho^{2}}}-\frac{-Z+\mu_{X}}{\sigma_{X} \sqrt{1-\rho^{2}}}\right) d Z .
\end{aligned}
$$


Once we have solved for $V$, the futures/forward price $F$ is given directly from Equation (A8). The implied repo rate in Equation (1) is given by simply solving for the interest rate that equates the present value of receiving $F$ in $N$ days to the current price of the CTD note $P$.

Evaluation of the density of $Z$ requires the correlation matrix of the three note prices $\tilde{P}_{j}, \tilde{P}_{k}$, and $\tilde{P}_{l}$. We estimate these covariances from the historical prices of the three cheapest-to-deliver notes for each futures contract. Specifically, for each date $t$ in the sample, we identify the three CTD notes for the futures contract that we reference as per our roll methodology. For these three CTD notes, we then collect all historical prices since issuance to date $t$ from the Bloomberg system. If there are more than 100 observations, we use a 100-day window to compute the correlation matrix of changes in note prices. If there are fewer than 100 observations, but more than 30 observations, we use all available prices to compute correlations, and if there are fewer than 30 observations, we use the last prior correlation matrix. Since the CTD status may change over time, the correlation matrix may not necessarily be computed using the same set of notes over time. However, our data shows very little variation in the set of CTD notes (changes occur only on 56 days out of 6,640 days). Due to missing note price data, prior correlations are used on 950 days. Our results are not sensitive to alternative rolling window specifications.

To evaluate the density of $Z$, we also use interest rate swaption volatility data to estimate the covariance matrix of $\tilde{P}_{j}, \tilde{P}_{k}$, and $\tilde{P}_{l}$. At each date $t$, we linearly interpolate the swaption volatility surface obtained from the Bloomberg system. To obtain annual basis point volatilities for the notes, we multiply the $n$-month into $m$-year swaption volatility by the forward swap rate of the same tenor which we calculate from the constant maturity swap (CMS) data using standard techniques. For the period, May 1995 through December 1996, daily swaption data is not available, and we use monthly data on one-month into fouryear, three-month into four-year, one-month into five-year, and three-month into five-year swaption volatilities, obtained from the broker Tradition Inc.

For the period from June 1991 to December 1995, swaption data is not available, and we use monthly cap volatilities from Tradition Inc. To estimate the covariance matrix from 1991 through 1995, we regress the swaption basis point volatilities on the cap basis point volatilities for the period 1995 to 1999 where we have both cap and swaption volatilities and use the fitted regression to estimate swaption basis point volatilities for the out-of-sample period from 1991 through 1995 where only cap volatilities are available.

Specifically, we regress one-month into four-year, one-month into five-year, three-month into four-year, and three-month into five-year swaption volatilities on interest rate cap volatilities for maturities of one, two, three, four, five, seven, 
and ten years. The annual basis point volatility of an $n$-year cap is obtained by multiplying the $n$-year swap rate by the $n$-year cap volatility. The annual basis point volatility of $n$-month into $m$-year swaption is calculated by multiplying the forward starting swap rate (one-month into four-year, one-month into fiveyear, three-month into four-year, and three-month into five-year) by the quoted swaption volatility of the $n$-month into $m$-year swaption. 


\section{Table A1}

Data Definitions and Sources.

Data

Frequency

Description and Source
Treasury Note Futures Data

3

6

$9 \quad$ Interest Rate Cap Volatilities

10 Earnings/Price Ratio

11 Dividend Yield

12 Funding Cost

13 Term Structure Slope
Daily

Five-year U.S. Treasury Note Futures end-of-day closing prices, trading volume open interest, margin requirements, and the set of deliverable Treasury notes and their conversion factors provided by the Chicago Mercantile Exchange (CME) and downloaded from the Bloomberg system.

Daily Five-year U.S. Treasury notes end-of-day prices, yields, coupon rates, issue, and maturity dates from the Bloomberg system and identified by CUSIPS.

General collateral overnight, and 1-week, 2-week, 3-week, 1-month, 2-month, 3 -month, 4-month, 5-month, and 6-month term repo rates from the Bloomberg system.

Daily Constant maturity Treasury rates from the Federal Reserve H.15 Selected Interest Rates Release.

Discount function out to 30 years bootstrapped from Treasury CMT rates as described in Liu, Longstaff, Mandell (2006).

Interest rate swaptions volatilities swaptions volatilities for $n$-month into $m$-year contracts $(n=1, \ldots, 12$ and $m=1, \ldots, 5)$ from January 1997 to December 2016 Data from the Bloomberg system.

Proprietary data provided by a major broker dealer (Tradition Inc.) from June 1991 to December 1996 consisting of swaption volatilities on 1-month into 4-year 3 -month into 4-year, 1-month into 5-year, and 3-month into 5-year swaptions.

Mid market constant maturity swap (CMS) rates for maturities of $1,2,3,5$,

and 10 years from June 1991 to December 2016. Data from the Bloomberg system.

Monthly Proprietary data provided by a major broker dealer (Tradition Inc.) from June 1991 to December 1996 consisting of at-the-money cap volatilities for $1-, 2-, 3-$ $4-, 5-, 7-$, and 10-year maturities.

Monthly Average earnings/price ratio for the banks in the banking industry portfolio defined by the Fama-French 49 industry classification. Data from WRDS.

Monthly Average dividend yield ratio for the banks in the banking industry portfolio defined by the Fama-French 49 industry classification. Data from WRDS.

Monthly The basis-point change in the average cost of funding earning assets for all banks as reported by the FDIC (https://www.fdic.gov/bank/statistical/).

Daily The basis-point difference between 10-year and 3-month Treasury rates. Data obtained from the Bloomberg system. 
Table A1 - Continued

\begin{tabular}{|c|c|c|c|}
\hline & Data & Frequency & Description and Source \\
\hline 14 & Libor-Treasury Spread & Daily & $\begin{array}{l}\text { The basis-point difference between the } 3 \text {-month Libor rate and the } 3 \text {-month } \\
\text { Treasury bill rate. Data from the Bloomberg system. }\end{array}$ \\
\hline 15 & Swap Spreads & Daily & $\begin{array}{l}\text { U.S. swap spreads for } 2-, 5-, 7-, 10-, 15-, 20-\text {, and } 30 \text {-year tenors. Data from the } \\
\text { Bloomberg system. }\end{array}$ \\
\hline 16 & Tier 1 Ratio & Quarterly & $\begin{array}{l}\text { Tier } 1 \text { capital as a percentage of risk-weighted assets. Data are averages over all } \\
\text { banks provided by the FDIC (https://www.fdic.gov/bank/statistical/). }\end{array}$ \\
\hline 17 & Core Ratio & Quarterly & $\begin{array}{l}\text { Tier } 1 \text { capital as a percentage of average total assets minus ineligible intangibles. } \\
\text { Data are averages over all banks provided by the FDIC (https://www.fdic.gov/ } \\
\text { bank/statistical/). }\end{array}$ \\
\hline 18 & Equity Ratio & Quarterly & $\begin{array}{l}\text { Total equity capital as a percentage of total assets. Data are averages over all } \\
\text { banks provided by the FDIC (https://www.fdic.gov/bank/statistical/). }\end{array}$ \\
\hline 19 & Total Capital Ratio & Quarterly & $\begin{array}{l}\text { Total risk-based capital as a percentage of risk-weighted assets. Data are averages } \\
\text { over all banks provided by the FDIC (https://www.fdic.gov/bank/statistical/). }\end{array}$ \\
\hline 20 & Non-Repo Capital Ratio & Quarterly & $\begin{array}{l}\text { Total broker-dealer equity expressed as a percentage of total broker-dealer assets } \\
\text { (excluding repo positions from total assets). Data are quarterly and obtained from } \\
\text { the Federal Reserve Financial Accounts of the United States (Z.1). }\end{array}$ \\
\hline 21 & Broker-Dealer Leverage & Quarterly & $\begin{array}{l}\text { The ratio of broker-dealer assets to broker-dealer assets less broker-dealer } \\
\text { liabilities. Data are quarterly averages across all broker-dealers and reported by } \\
\text { the Federal Reserve in the Financial Accounts of the United States (Z.1). }\end{array}$ \\
\hline 22 & Broker-Dealer Holdings & Quarterly & $\begin{array}{l}\text { Outright positions in Treasury securities by broker-dealers. Data are quarterly } \\
\text { averages across all broker-dealers and reported by the Federal Reserve in the } \\
\text { Financial Accounts of the United States (Z.1). }\end{array}$ \\
\hline 23 & Broker-Dealer Asset Growth & Quarterly & $\begin{array}{l}\text { Quarterly percentage changes in total broker dealer assets. Data are quarterly } \\
\text { averages across all broker-dealers and reported by the Federal Reserve in the } \\
\text { Financial Accounts of the United States (Z.1). }\end{array}$ \\
\hline
\end{tabular}




\section{Table A2}

Example of the Impact from Direct/Synthetic Positions in a Treasury Security on the SLR. This table example shows a financial institution (FI) subject to Basel III supplementary leverage ratio (SLR) requirements that finances a $\$ 40 \mathrm{~m}$ position in a Treasury Note using two alternative approaches. Under the first alternative, the FI purchases the note outright and under the second alternative, the FI creates synthetic exposure via the futures market. As shown, the FI fails to meet the SLR requirement of having a $5 \%$ leverage ratio using the direct approach.

\section{Direct Position}

\begin{tabular}{lrlr}
\hline Assets & \multicolumn{2}{l}{ Liabilities } & \\
\hline Cash & 11 & Deposits & 182 \\
5 Year Treasury Note & 60 & Short-term Debt & 42 \\
Lending to Banks & 30 & Shareholder' Funds & \\
Housing loans with mortgages & 52 & Ordinary capital & 7 \\
Commercial loans & 64 & Redeemable preference shares & 3 \\
Goodwill & 3 & Retained earnings & 8 \\
Shareholding in other bank & 3 & Revaluation reserve & 4 \\
Fixed assets & 25 & & \\
General provision for bad debts & -2 & & \\
& $\overline{246}$ & & 246 \\
\hline \hline Off-Balance Sheet & 0 & & 0 \\
\hline \hline Tier 1 Capital & & Total Leverage Exposure & \\
\hline Ordinary capital (or equity) & 7 & On-balance Sheet Assets & 246 \\
Retained earnings & 8 & Derivatives Exposure & \\
less Goodwill & 3 & Other Exposures & \\
& $\overline{18}$ & & 246 \\
\hline \hline SLR & $4.88 \%$ & & \\
\hline
\end{tabular}

Synthetic Position

\begin{tabular}{|c|c|c|c|}
\hline Assets & & Liabilities & \\
\hline Cash & 11 & Deposits & 182 \\
\hline 5 Year Treasury Note & 20 & Short-term Debt & \\
\hline Lending to Banks & 30 & Shareholders' Funds & \\
\hline Housing loans with mortgages & 52 & Ordinary capital & \\
\hline Commercial loans & 64 & Redeemable preference shares & \\
\hline Goodwill & 3 & Retained earnings & \\
\hline Shareholding in other bank & 3 & Revaluation reserve & \\
\hline Fixed assets & 25 & & \\
\hline \multirow[t]{2}{*}{ General provision for bad debts } & -2 & & \\
\hline & $\overline{206}$ & & $\overline{206}$ \\
\hline Off-Balance Sheet & 40 & & \\
\hline Tier 1 Capital & & Total Leverage Exposure & \\
\hline Ordinary capital (or equity) & 7 & On-balance Sheet Assets & 206 \\
\hline Retained earnings & 8 & Derivatives Exposure ${ }^{*}$ & \\
\hline \multirow[t]{2}{*}{ less Goodwill } & $\underline{3}$ & Other Exposures & \\
\hline & $\overline{18}$ & & \\
\hline SLR & $5.83 \%$ & & \\
\hline
\end{tabular}




\section{Table A3}

Example of the Impact from Direct/Synthetic Positions in a Treasury Security on the LCR. This table shows a financial institution (FI) subject to Basel III liquidity coverage ratio (LCR) requirements that finances a $\$ 1 \mathrm{~m}$ position in a Treasury Note using a repo transaction. As shown, the FI fails to meet the LCR requirement of having a LCR ratio greater than $100 \%$ when it finances a virtually risk-free government bond position via repo. In contrast, by creating a synthetic $\$ 1$ exposure via the futures market, the FI's LCR ratio would be unaffected.

Synthetic Position in Treasury note via futures

\begin{tabular}{lrlr}
\hline Assets & \multicolumn{2}{l}{ Liabilities } \\
\hline Gov. Bonds & 5 & Deposits \\
Retail loans (due in 30 days or less) & 18 & Shorterm funding (due in 30 days or less) & 80 \\
Longterm loans & $\frac{77}{100}$ & Longterm wholesale funding & 10 \\
& 1 & & 100 \\
\hline \hline Off-Balance Sheet & \multicolumn{2}{l}{ High-Quality Liquid Assets (HQLA) } \\
\hline \hline Capital In-/Outflows & 9 & HQLA \\
\hline Capital Inflows & 14 & \\
Capital Outflows & 5 & \\
Net Capital Flows & $100.00 \%$ & \\
\hline \hline LCR & & \\
\hline
\end{tabular}

Treasury note financed via repo

\begin{tabular}{lrlr}
\hline Assets & Liabilities & \\
\hline Gov. Notes & $(1)$ & 1 & Repo \\
Gov. Bonds & 5 & Deposits \\
Retail loans (due in 30 days or less) & 18 & Shorterm funding (due in 30 days or less) & 80 \\
Longterm loans & 77 & Longterm wholesale funding & 10 \\
& $\overline{101}$ & & 10 \\
\hline
\end{tabular}

\begin{tabular}{|c|c|c|}
\hline Off-Balance Sheet & 0 & \\
\hline Capital In-/Outflows & & High-Quality Liquid Assets (HQLA) \\
\hline Capital Inflows ${ }^{(2)}$ & 9 & $\mathrm{HQLA}^{(1)}$ \\
\hline Capital Outflows & 15 & \\
\hline Net Capital Flows & 6 & \\
\hline LCR & $83.33 \%$ & \\
\hline $\begin{array}{l}{ }^{(1)} \text { For assets to qualify as } \\
\text { security holding, only the } \\
\text { requirements. } \\
(2) \text { The LCR defines specif } \\
\text { rate retail loan of } 0 \% \text {, H } \\
\text { haircut on repo } 100 \% \text { (ap } \\
\text { runoff rate repo borrowin } \\
\text { Allahrakha, Cetina, Muny }\end{array}$ & $\begin{array}{l}\text { cannot be } \\
\text { ed with ma } \\
\text { ff rates, as } \\
\text { overnment } \\
\text { runoff rat } \\
\text { gy repo wit }\end{array}$ & $\begin{array}{l}\text { financed in repo. Thus, when a FI is using repo to fund a } \\
\text { turing secured funding because the collateral fails HQLA } \\
\text { vell as haircuts. The calculations use the following: Inflow } \\
\text { securities of } 0 \% \text { (applies to all U.S. Treasury securities), } \\
\text { deposit of } 5 \% \text {, runoff rate wholesale borrowing of } 100 \% \text {, } \\
\text { h } 30 \text { days or less). These assumptions are consistent with }\end{array}$ \\
\hline
\end{tabular}




\section{REFERENCES}

Adrien, Tobias, and Nina Boyarchenko, 2012, Intermediary Leverage Cycles and Financial Stability, Federal Reserve Bank of New York Staff Reports, no. 567.

Adrien, Tobias, Erkko Etula, and Tyler Muir, 2014, Financial Intermediaries and the Cross-Section of Asset Returns, Journal of Finance 69, 2557-2596.

Adrien, Tobias, Michael Fleming, Jonathan Goldberg, Morgan Lewis, Fabio Natalucci, and Jason Wu, 2013, Dealer Balance Sheet Capacity and Market Liquidity during the 2013 Selloff in Fixed-Income Markets, Liberty Street Economics, October 16, 2013, Federal Reserve Bank of New York.

Adrien, Tobias, Michael Fleming, Or Shachar, and Erik Vogt, 2016, Market Liquidity after the Financial Crisis, Working paper, Federal Reserve Bank of New York.

Adrien, Tobias, Michael Fleming, Daniel Stackman, and Erik Vogt, 2015, What's Driving Dealer Balance Sheet Stagnation?, Liberty Street Economics, August 21, 2015, Federal Reserve Bank of New York.

Adrien, Tobias, and Hyun Song Shin, 2010, Liquidity and Leverage, Journal of Financial Intermediation 19, 418-437.

Aitken, James, and Manmohan Singh, 2010, The (Sizable) Role of Rehypothecation in the Shadow Banking System, IMF Working Paper, No. 10/172.

Albanese, Claudio, and Leif Andersen, 2014, Accounting for OTC Derivatives: Funding Adjustments and the Re-Hypothecation Option, Working paper, CASS School of Business.

Allahrakha, Meraj, Jill Cetina, and Benjamin Munyan, 2016, Do Higher Capital Standards Always Reduce Bank Risk? The Impact of the Basel Leverage Ratio on the U.S. Tri-Party Repo Market, Working paper, Office of Financial Research.

Allahrakha, Meraj, Paul Glasserman, and H. Peyton Young, 2015, Systemic Importance Indicators for 33 U.S. Bank Holding Companies: An Overview of Recent Data, Office of Financial Research, OFR Brief Series, February.

Allen, Franklin, and Douglas Gale, 2000, Financial Contagion, Journal of Political Economy 108, 1-33.

Andersen, Leif, Darrell Duffie, and Yang Song, 2016, Funding Value Adjustments, Working paper, Stanford University.

Baklanova, Viktoria, Adam M. Copeland, and Rebecca McCaughrin, 2015, Ref- 
erence Guide to U.S. Repo and Securities Lending Markets, Office of Financial Research Working Paper No. 15-17, September.

Bao, Jack, Maureen O'Hara, and Alex Zhou, 2016, The Volcker Rule and MarketMaking in Times of Stress, Working paper, The Federal Reserve Board.

Baranova, Yuliya, Zijun Liu, and Joseph Noss, 2016, The Role of Collateral in Supporting Liquidity, Staff Working Paper 609, Bank of England.

Barnhill, Theodore M., 1990, Quality Option Profits, Switching Option Profits, and Variation Margin Costs: An Evaluation of their Size and Impact on Treasury Bond Futures Prices, Journal of Financial and Quantitative Analysis 25, 65-86.

Basak, Suleyman, and Benjamin Croitoru, 2000, Equilibrium Mispricing in a Capital Market with Portfolio Constraints, Review of Financial Studies 13, 715748.

Basak, Suleyman, and Anna Pavlova, 2013, Asset Prices and Institutional Investors, American Economic Review 103, 1728-1758.

Benninga, Simon, and Michael Smirlock, 1985, An Empirical Analysis of the Delivery Option, Marking to Market, and the Pricing of Treasury Bond Futures, Journal of Futures Markets 5, 361-374.

Benninga, Simon, and Zvi Wiener, 1999, An Investigation of Cheapest to Deliver on Treasury Bond Futures Contracts, Journal of Computational Finance 2, 39-55.

Bowen, Christopher, Joe Hawryzs, Frederick Sturm, and Anthony Zangrill, 2016, The Treasury Futures Delivery Process, Tech. Report, CME Group.

Boyle, Phelim, 1989, The Quality Option and Timing Option in Futures Contracts, Journal of Finance 44, 101-113.

Brandt, Michael W., and Kenneth A. Kavajecz, 2004, Price Discovery in the U.S. Treasury Market: The Impact of Orderflow and Liquidity on the Yield Curve, Journal of Finance 59, 2623-2754.

Brandt, Michael W., Kenneth A., Kavajecz, and Shane E. Underwood, 2007, Price Discovery in the Treasury Futures Market, Journal of Futures Markets 27, 1021-1051.

Brenner, Menachem, and Dan Galai, 1986, Implied Interest Rates, Journal of Business 59, 493-507.

Brunnermeier, Markus K., Stefan Nagel, and Lasse H. Pedersen, 2008, Carry Trades and Currency Crashes, ed. Kenneth Rogoff, Michael Woodford, \& Daron Acemoglu, NBER Macroeconomics Annual 23, 313-347. 
Brunnermeier, Markus, and Lasse H. Pedersen, 2009, Market Liquidity and Funding Liquidity, Review of Financial Studies 22, 2201-2238.

Brunnermeier, Markus, and Yuliy Sannikov, 2014, A Macroeconomic Model with a Financial Sector, American Economic Review 104, 379-421.

Burghardt, Galen, and Terry M. Belton, 2005, The Treasury Bond Basis-An InDepth Analysis for Hedgers, 3rd Edition, McGraw-Hill Professional Publishing,

Carr, Peter, 1988, The Valuation of Sequential Exchange Opportunities, The Journal of Finance 43, 1235-1256.

Chance, Don M., and Michael L. Hemler, 1993, The Impact of Delivery Options on Futures Prices: A Survey, Journal of Futures Markets 13, 127-155.

Chen, Mirand, Praveen Korapaty, and Mahesh Swaminathan, 2016, What's Balance Sheet got to do with Asset Prices?, Credit Suisse Fixed Income Research, 18 February, 1-18.

Choudhry, Moorad, 2006, An Introduction to Repo Markets, 3rd Edition, Wiley.

Chowdhry, Bhagwan, and Vikram Nanda, 1998, Leverage and Market Stability: The Role of Margin Rules and Price Limits, Journal of Business 71, 179-210.

Copeland, Adam, Antoine Martin, and Michael Walker, 2010, The Tri-Party Repo Market before the 2010 Reforms, Federal Reserve Bank of New York, Staff Reports, No. 477, November.

Copeland, Adam, Darrell Duffie, Antoine Martin, and Susan McLaughlin, 2012, Key Mechanics of the U.S. Tri-Party Repo Market, FRBNY Economic Policy Review November, 17-28.

Copeland, Adam, Antoine Martin, and Michael Walker, 2014, Repo Runs: Evidence from the Tri-Party Repo Market, Journal of Finance 69, 2343-2380.

Cox, John C., Jonathan E. Ingersoll, Jr., and Stephen A. Ross, 1981, The Relation Between Forward Prices and Futures Prices, Journal of Financial Economics $9,321-346$.

Danielsson, Jon, Hyun Song Shin, and Jean-Pierre Zigrand, 2011, Balance Sheet Capacity and Endogenous Risk, Working paper, London School of Economics.

Du, Wenxin, Alexander Tepper, and Adrien Verdelhan, 2017, Deviations from Covered Interest Rate Parity, NBER Working Paper 23170.

Duffie, Darrell, 2010, Asset Price Dynamics with Slow-Moving Capital, Journal of Finance 65, 1237-1267. 
Duffie, Darrell, 2016, Financial Regulatory Reform After the Crisis: An Assessment, Management Science, forthcoming.

Duffie, Darrell (2017), FVA: Off the Mark, Risk.net, 24 January 2017, available at http://www.risk.net/cutting-edge/views/2480639/fva-off-the-mark

Eisfeldt, Andrea, and Adriano Rampini, 2009, Leasing, Ability to Repossess, and Debt Capacity, Review of Financial Studies 22, 16 21-1657,

Engle, Robert F., Michael J. Fleming, Eric Ghysels, and Giang Nguyen, 2012, Liquidity, Volatility, and Flights to Safety in the U.S. Treasury Market: Evidence from a New Class of Dynamic Order Book Models, Federal Reserve Banks of New York Staff Report No. 590.

Fett, Nicolas, and Richard Haynes, 2017, Liquidity in Selected Futures Markets, Commodity Futures Trading Commission Working paper.

Fleckenstein, Matthias, Francis A. Longstaff, Hanno Lustig, 2014, The TIPSTreasury Puzzle, Journal of Finance 69, 2151-2197.

Fleming, Michael J., 2003, Measuring Treasury Market Liquidity, Federal Reserve Bank of New York, Economic Policy Review 9, 83-108.

Fleming, Michael J., and Asani Sarkar, 1999, Liquidity in U.S. Treasury Spot and Futures Markets, Federal Reserve Bank of New York, Market Liquidity Research Findings and Selected Policy Implications.

Fostel, Ana, and John Geanakoplos, 2008, Collateral Restrictions and Liquidity Under-Supply: A Simple Model, Economic Theory 35, 441-467.

Gârleanu, Nicolae, and Lasse H. Pedersen, 2011, Margin-Based Asset Pricing and Deviations from the Law of One Price, Review of Financial Studies 22, 4259-4299.

Gay, Gerald, and Steven Manaster, 1984, The Quality Option Implicit in Futures Contracts, Journal of Financial Economics 13, 353-370.

Golez, Benjamin, Jens C. Jackwerth, and Anna Slavutskaya, 2017, Funding Illiquidity Implied by S\&P 500 Derivatives, Working paper, University of Konstanz.

Gorton, Gary, and Andrew Metrick, 2012, Securitized Banking and the Run on Repo, Journal of Financial Economics 104, 425-451

Griffiths, Mark D., and Drew B. Winters, 1997, On a Preferred Habitat for Liquidity at the Turn-of-the-Year: Evidence from the Term-Repo Market, Journal of Financial Services Research 12, 21-38.

Gromb, Denis, and Dimitri Vayanos, 2002, Equilibrium and Welfare in Markets 
with Financial Constrained Arbitrageurs, Journal of Financial Economics 66, 361-407.

Gunther, Nicolas L., Robert M. Anderson, Lisa R. Goldberg, 2016, The Implied Futures Financing Rate, Working paper, University of California, Berkeley.

He, Zhiguo, and Arvind Krishnamurthy, 2012, A Model of Capital and Crises, Review of Economic Studies 79, 735-777.

He, Zhiguo, and Arvind Krishnamurthy, 2013, Intermediary Asset Pricing, American Economic Review 103, 732-770.

He, Zhiguo, Bryan Kelly, and Asaf Manela, 2016, Intermediary Asset Pricing: New Evidence from Many Asset Classes, Working Paper, University of Chicago.

Hegde, Shantaram P., 1989, On the Value of the Implicit Delivery Options, Journal of Futures Markets 5, 421-437.

Hemler, Michael L., 1990, the Quality Delivery Option in Treasury Bond Futures Contracts, Journal of Finance X, 1565-1586.

Holder, Mark E., and Sinha, Amit K., 2009, Bid-Ask Spread Determinants in Treasury Note Futures Contracts at the Chicago Board of Trade, Journal of Financial and Economic Practice (Fall), 1-14.

Holod, Dmytro, and Yuriy Kitsul, 2010, Capital Constraints and Systematic Risk, Working paper, Federal Reserve Board.

Hull, John, and Alan White, 2012, The FVA Debate, Risk 25th Anniversary Edition, July, 83-85.

Hull John, and Alan White, 2014a, Valuing Derivatives: Funding Value Adjustments and Fair Value Financial Analysts Journal 70, 3 (May/June), 46-56.

Hull, John, and Alan White, 2014b, Collateral and Credit Issues in Derivatives Pricing Journal of Credit Risk 10, 3, 3-28.

International Capital Market Association, 2015, Perspectives from the Eye of the Storm: The Current State and Future Evolution of the European Repo Market, ICMA Working paper, November 2015.

Jermann, Urban J., 2016, Negative Swap Spreads and Limited Arbitrage, Working paper, University of Pennsylvania.

Johannes, Michael, and M. Suresh Sundaresan, 2007, The Impact of Collateralization on Swap Rates, Journal of Finance 62, 383-410 
Johnston, Elizabeth T., William A. Kracaw, and John J. McConnell, 1991, Dayof-the-Week Effects in Financial Futures: An Analysis of GNMA, T-Bond, TNote, and T-Bill Contracts, The Journal of Financial and Quantitative Analysis $26,23-44$.

Kane, Alex, and Alan J. Marcus, 1986a, The Quality Option in the Treasury Bond Futures Market: An Empirical Assessment, Journal of Futures Markets 6, 231-248.

Kane, Alex, and Alan J. Marcus, 1986b, Valuation and Optimal Exercise of the Wild Card Option in the Treasury Bond Futures Market, Journal of Finance 41, 195-208.

Kho, Bong-Chan, Dong Lee, and Rene M. Stulz, 2000, U.S. Banks, Crises, and Bailouts: From Mexico to LTCM, American Economic Review 90, 28-31

Kiema, Ilkka, and Esa Jokivuolle, 2014, Does a Leverage Ratio Requirement Increase Bank Stability?, Journal of Banking and Finance 39, 240-254.

Kiyotaki, Nobuhiro, and John Moore, 1997, Credit Cycles, Journal of Political Economy 105, 211-248.

Klingler, Sven, and M. Suresh Sundaresan, 2016, An Explanation of Negative Swap Spreads: Demand for Duration from Underfunded Pension Plans, Working paper, Columbia University.

Kondor, Peter, and Dimitri Vayanos, 2015, Liquidity Risk and the Dynamics of Arbitrage Capital, Working Paper London School of Economics.

Krishnamurthy, Arvind, 2002, The Bond/Old-Bond Spread, Journal of Financial Economics 66, 463-506.

Krishnamurthy, Arvind, 2003, Collateral Constraints and the Amplification Mechanism, Journal of Economic Theory 111, 277-292.

Krishnamurthy, Arvind, 2010, Amplification Mechanisms in Liquidity Crises, American Economic Journal - Macroeconomics 2, 1-30.

Krishnamurthy, Arvind, Stefan Nagel, and Dmitri Orlov, 2014, Sizing Up Repo, Journal of Finance 69, 2381-2417.

Kronstein, Jonathan, J. Lao, Agha Mirza, and Frederick Sturm, 2016, Treasury Futures Delivery Options, Basis Spreads, and Delivery Tails, Tech. Report, CME Group.

Kyle, Albert S., and Wei Xiong, 2001, Contagion as a Wealth Effect, Journal of Finance 56, 1401-1440. 
Liu, Jun, Francis A. Longstaff, and Ravit Mandell, 2006, The Market Price of Risk in Interest Rate Swaps: The Roles of Default and Liquidity Risk, Journal of Business 79, 2337-2360.

Longstaff, Francis A., 1995, Option Prices and the Martingale Restriction, Review of Financial Studies 8, 1091-1124.

Mackenzie Smith, Robert, 2016, L'exception francaise: why French banks dominate US repo trading, Risk.net, September 1, 2016, available at: http://www.risk. net/derivatives/2469133/lexception-francaise-why-french-banks-dominate-us-re po-trading.

Manaster, Steven, and Richard J. Rendleman, 1982, Option Prices as Predictors of Equilibrium Stock Prices, Journal of Finance 37, 1043-1057.

Mizrach, Bruce, and Christopher J. Neely, 2008, Information Shares in the U.S. Treasury Market, Journal of Banking and Finance 32, 1221-1233.

Munyan, Benjamin, 2015, Regulatory Arbitrage in Repo Markets, Working paper, Vanderbilt University.

Nadarajah, Saralees, and Samuel Kotz, 2008, Exact Distribution of the Max/Min of Two Gaussian Random Variables, IEEE Transactions on Very Large Scale Integration (VLSI) Systems 16, 210-212.

Naranjo, Lorenzo, 2009, Implied Interest Rates in a Market with Frictions, Working paper, New York University.

Newey, Whitney K., and Kenneth D. West, 1987, A Simple, Positive Semidefinite, Heteroskedasticity and Autocorrelation Consistent Correlation Matrix, Econometrica 59, 703-708.

Omprakash, Anand, 2014, A New Normal in Equity Repo, Risk Management 29 (March), 20-23.

Owens, Edward L., and Joanna Shuang Wu, 2014, Quarter-end Repo Borrowing Dynamics and Bank Risk Opacity, Working paper, University of Rochester.

Reinhart, Carmen M., and Kenneth S. Rogoff, 2014. This Time is Different: A Panoramic View of Eight Centuries of Financial Crises, Annals of Economics and Finance, Society for AEF, vol. 15(2), pages 1065-1188, November.

Ritchken, Peter, and L. Sankarsubramanian, 1992, Pricing the Quality Option in Treasury Bond Futures, Mathematical Finance 2, 197-214.

Romer, Christina D., and David H. Romer, 2015, New Evidence on the Impact of Financial Crises in Advanced Countries. NBER Working paper, No. 21021. 
Ronn, Aimee Gerbarg, and Ehud Ronn, 1989, The Box Spread Arbitrage Condition: Theory, Tests, and Investment Strategies, Review of Financial Studies 2, 91-108.

Schularick, Moritz, and Alan M. Taylor, 2012, Credit Booms Gone Bust: Monetary Policy, Leverage Cycles, and Financial Crises, 1870-2008, American Economic Review 102, 1029-1061.

Sharpe, Steven A., and Hien H. Nguyen, 1995, Capital Market Imperfections and the Incentive to Lease, Journal of Financial Economics 39, 271-294.

Song, Zhaogang, and Haoxiang Zhu, 2016, Mortgage Dollar Roll, Working paper, MIT.

Tuckman, Bruce, 2013, Embedded Financing: The Unsung Virtue of Derivatives, Journal of Fixed Income 21 (Fall), 73-82.

Xiong, Wei, 2001, Convergence Trading with Wealth Effects: An Amplification Mechanism in Financial Markets, Journal of Financial Economics 62, 247-292. 


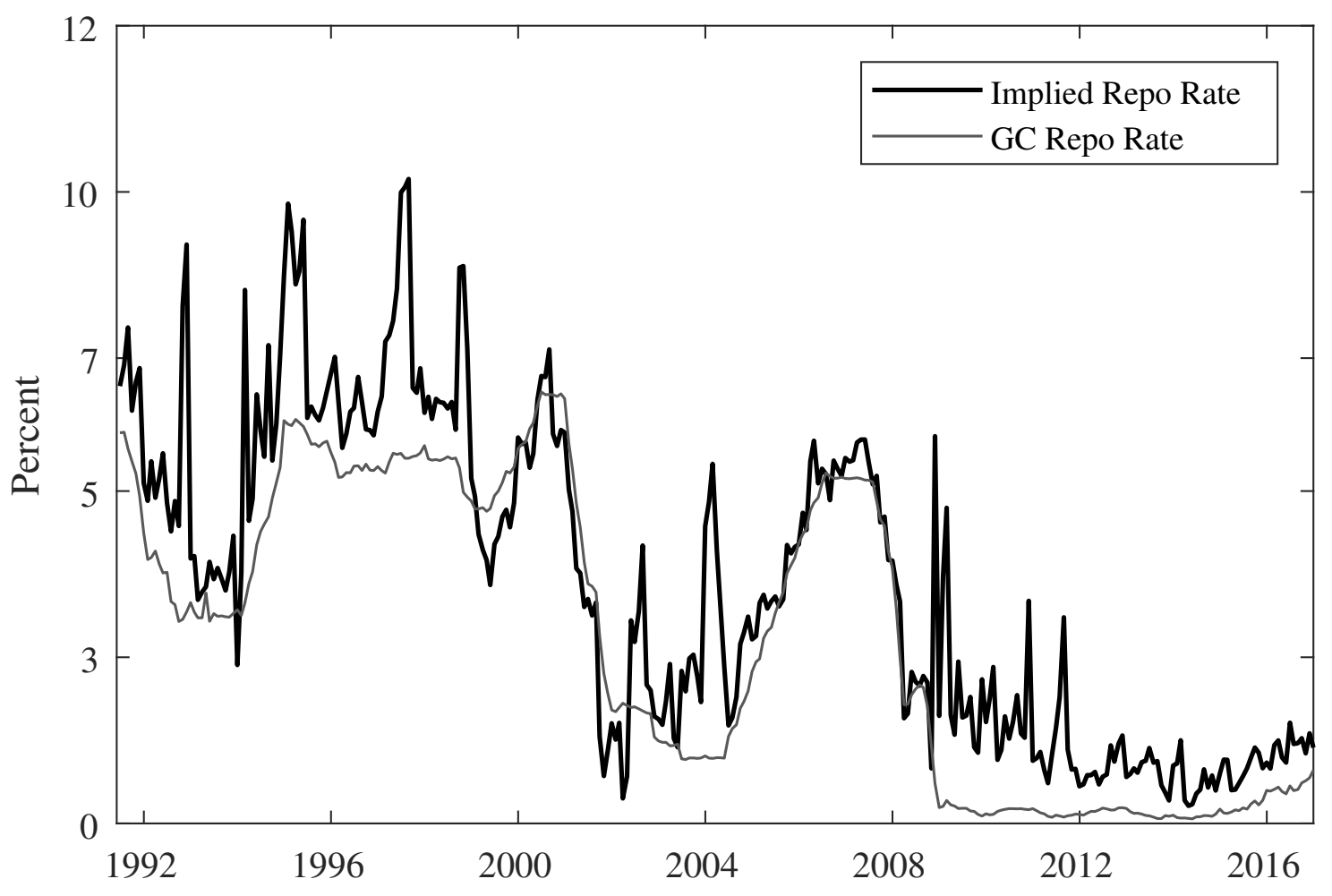

Figure 1. The Implied Repo and Term Repo Rates. This figure shows the implied repo rate from five-year Treasury note futures contracts and the corresponding term general collateral Treasury repo rate. The rates shown are monthly averages of daily rates. 


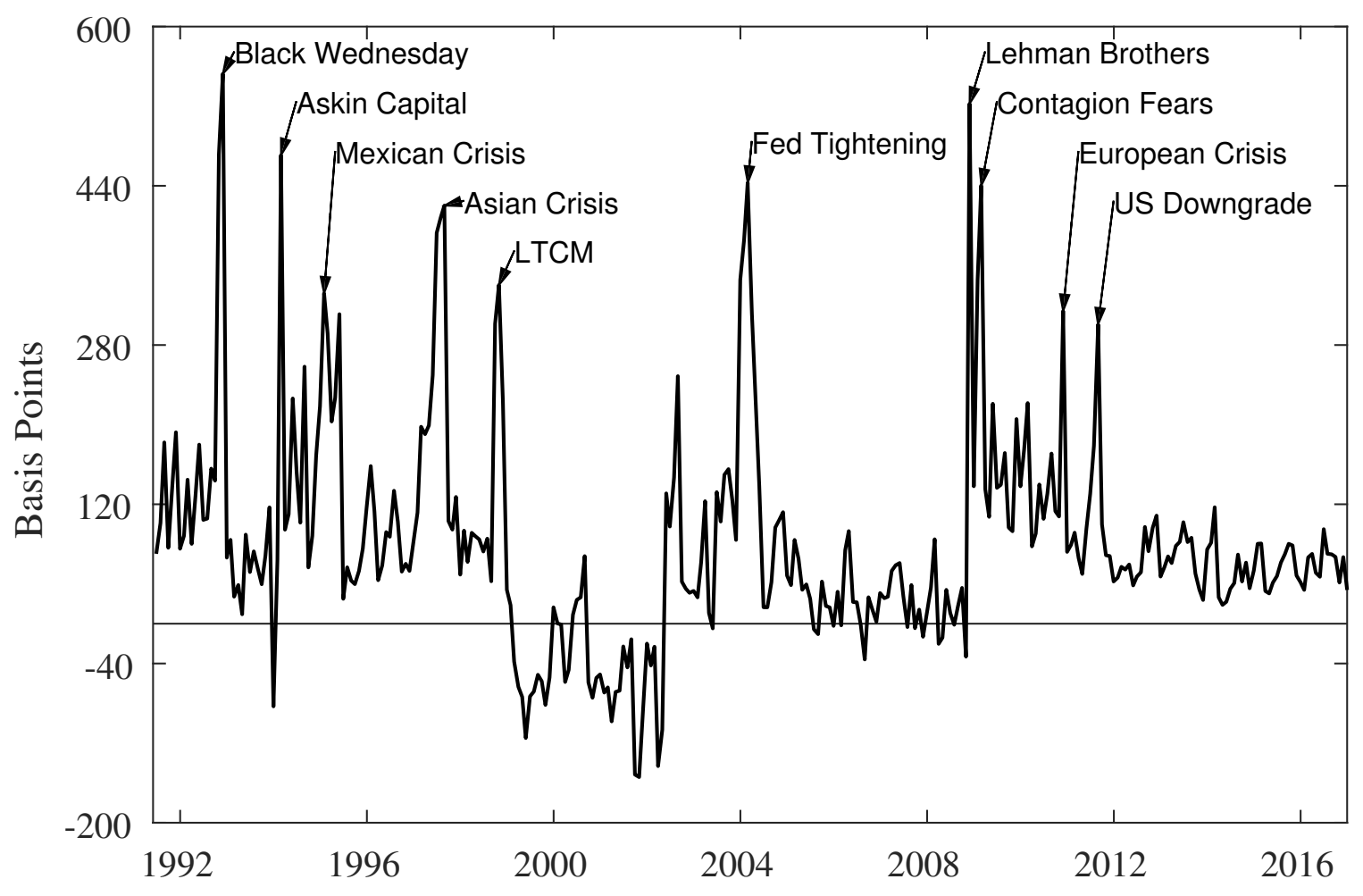

Figure 2. Balance Sheet Costs. This figure plots the time series of balance sheet costs which are computed as the difference between the implied repo rate and the corresponding term general collateral Treasury repo rate. Key financial market events are superimposed on the plot. The balance sheet costs are expressed in basis points and are shown as monthly averages of daily values. 
Table 1

Timeline of Major Events and Changes in Financial Regulation. This table presents a timeline of economic events affecting financial markets and changes in financial regulations. Financial and economic crises are from Kho, Lee, and Stulz (2000), Romer and Romer (2015), and Reinhart and Rogoff (2008). Data on financial regulation and financial market conditions are from the Basel Committee on Banking Supervision, the Federal Register, FDIC, and the OECD Economic Outlook. The sample period is from June 3, 1991 to December 30, 2016.

Dec 1991

Sep 1992

Apr 1994

Dec 1994

Aug 1997

Aug 1998

Aug 1998

Nov 1998

Jun 1999

Nov 2002

Dec 2003

Apr 2004

Jun 2004

Jun 2006

Oct 2007

Sep 2008

Mar 2009

Jul 2009

Jan 2010

May 2010

Jul 2010

Nov 2010

Dec 2010

Feb 2011

Apr 2011

Aug 2011

Jun 2012

Jul 2013

Oct 2013

Sep 2014
FDIC Improvement Act - Regulators introduce new bank capital thresholds. Black Wednesday - UK withdraws from European Exchange Rate Mechanism. Askin Capital Management - Collapse sends shock wave through mortgage market. Mexican Crisis - Mexico forced to devalue the Peso, receives IMF aid in January. Asian Crisis - Thailand forced to devalue the Baht, receives IMF bailout. Russian Financial Crisis - Russia declares default on government debt. Long Term Capital Management Crisis - Federal Reserve organizes bailout of LTCM. Crisis in Brazil - IMF steps in as capital outflows from Brazil surge.

Basel II - Basel committee proposes new capital adequacy framework. Yield curve steepens as the Fed decreases the Fed Funds rate to 1.25 percent. Long-term yields increase due to signs of monetary tightening and robust growth. Net Capital Rule - SEC issues new rule to determine net capital for broker dealers. Basel II - Final Basel II framework includes strict minimum capital requirements. Basel II - Basel Committee finalizes rules for trading books of banks. Subprime Mortgage crisis - Distress in interbank markets due to loan losses. Lehman Brothers bankruptcy - Uncertainty about solvency of banks. Fears of contagion from subprime markets and its impact on banks' balance sheets. Dodd-Frank Act - Proposal to establish strict bank capital and liquidity rules. Collins Amendment - Proposal to establish Basel III leverage and capital rules. European Debt Crisis - Fears of default from Portugal, Ireland, Greece and Spain. Dodd-Frank Act signed into law, mandating strict capital requirements for banks. European Debt Crisis - Bailout of Ireland, concerns about Portugal and Italy. Basel III - Framework tightens banks' capital and liquidity requirements. European Debt Crisis - Greece receives second bailout and restructures its debt. European Debt Crisis - Portugal receives IMF bailout, fears of contagion in EU. $\mathrm{S} \& \mathrm{P}$ downgrades the credit rating of the United States.

Supplementary Leverage Ratio - Leverage includes on- and off-balance sheet risks. Enhanced Supplementary Leverage Ratio - Stricter leverage rules for large banks. Liquidity Coverage Ratio - Requirement for banks to hold liquid assets. Supplementary Leverage Ratio and Liquidity Coverage Ratio finalized. 
Table 2

Summary Statistics for Five-Year Treasury Note Futures Contracts. This table presents summary statistics for the five-year Treasury note futures contracts. Year and Months denote the year and contract expiration months during that year in the sample. Vol and Open denote the average daily total trading volume and open interest across all Treasury note future contracts traded during the year. Min, Ave, and Max denote the minimum, average, and maximum prices for the futures contracts during the vear. Num, Time, and Coup denote the average number of notes deliverable, the average time to maturity at issuance of the deliverable notes, and the average coupon rates for the deliverable bonds for all contracts during the year. Init and Maint denote the average initial and maintenance margins for speculators for the year (expressed as dollars per contract).

\begin{tabular}{|c|c|c|c|c|c|c|c|c|c|c|c|}
\hline Year & Months & Vol & Open & Min & Ave & Max & Num & Time & Coup & Init & Maint \\
\hline 1991 & 9,12 & 8,573 & 40,902 & 98.61 & 101.69 & 106.83 & 9.00 & 5.0146 & 7.5139 & 945 & 700 \\
\hline 1992 & $3,6,9,12$ & 11,380 & 57,358 & 99.91 & 105.02 & 111.61 & 12.00 & 5.0024 & 6.5243 & 945 & 700 \\
\hline 1993 & $3,6,9,12$ & 14,316 & 64,678 & 102.25 & 109.19 & 114.23 & 10.75 & 5.0014 & 5.3889 & 945 & 700 \\
\hline 1994 & $3,6,9,12$ & 22,769 & 75,976 & 100.34 & 106.79 & 113.03 & 9.00 & 5.0018 & 5.8889 & 945 & 700 \\
\hline 1995 & $3,6,9,12$ & 23,967 & 68,873 & 99.06 & 103.50 & 109.89 & 9.25 & 5.0032 & 6.8542 & 945 & 700 \\
\hline 1996 & $3,6,9,12$ & 19,385 & 60,077 & 103.72 & 107.29 & 111.41 & 9.50 & 5.0001 & 6.0486 & 1,215 & 900 \\
\hline 1997 & $3,6,9,12$ & 35,001 & 85,722 & 103.53 & 106.07 & 108.73 & 10.00 & 5.0013 & 6.2847 & 1,114 & 825 \\
\hline 1998 & $3,6,9,12$ & 37,762 & 128,845 & 106.09 & 109.66 & 115.97 & 8.50 & 5.0007 & 5.5608 & 996 & 738 \\
\hline 1999 & $3,6,9,12$ & 33,254 & 121,507 & 106.84 & 110.87 & 116.28 & 3.25 & 5.0009 & 5.1745 & 1,148 & 850 \\
\hline 2000 & $3,6,9,12$ & 46,641 & 191,548 & 96.41 & 98.81 & 103.16 & 2.50 & 5.0033 & 6.1198 & 890 & 638 \\
\hline 2001 & $3,6,9,12$ & 60,960 & 193,859 & 99.69 & 102.62 & 110.31 & 2.00 & 5.0027 & 5.1719 & 1,080 & 800 \\
\hline 2002 & $3,6,9,12$ & 99,575 & 278,873 & 99.95 & 103.35 & 114.34 & 2.50 & 5.0027 & 3.8125 & 1,316 & 975 \\
\hline 2003 & $3,6,9,12$ & 139,529 & 380,050 & 99.95 & 105.58 & 117.69 & 5.00 & 5.0020 & 3.1250 & 1,215 & 900 \\
\hline 2004 & $3,6,9,12$ & 180,234 & 508,081 & 100.00 & 108.82 & 115.19 & 10.50 & 5.0027 & 3.2879 & 979 & 725 \\
\hline 2005 & $3,6,9,12$ & 200,707 & 502,924 & 105.12 & 108.16 & 112.47 & 11.00 & 5.0016 & 3.7557 & 675 & 500 \\
\hline 2006 & $3,6,9,12$ & 227,845 & 467,887 & 102.88 & 105.84 & 109.20 & 10.50 & 5.0016 & 4.5040 & 540 & 413 \\
\hline 2007 & $3,6,9,12$ & 306,553 & 740,968 & 102.88 & 105.28 & 111.06 & 11.25 & 5.0028 & 4.5450 & 827 & 613 \\
\hline 2008 & $3,6,9,12$ & 346,137 & 840,356 & 103.17 & 109.66 & 122.30 & 11.00 & 5.0029 & 3.2926 & 1,586 & 1,175 \\
\hline 2009 & $3,6,9,12$ & 199,759 & 422,587 & 107.97 & 114.68 & 120.48 & 10.75 & 5.0010 & 2.2778 & 1,384 & 1,025 \\
\hline 2010 & $3,6,9,12$ & 258,682 & 423,986 & 110.10 & 115.55 & 122.25 & 11.00 & 5.0015 & 2.1591 & 1,131 & 838 \\
\hline 2011 & $3,6,9,12$ & 353,301 & 647,732 & 109.32 & 117.52 & 124.13 & 10.75 & 5.0035 & 1.6676 & 1,215 & 900 \\
\hline 2012 & $3,6,9,12$ & 275,396 & 656,619 & 112.60 & 121.19 & 124.95 & 10.25 & 5.0026 & 0.8849 & 810 & 600 \\
\hline 2013 & $3,6,9,12$ & 348,569 & 808,238 & 118.46 & 122.63 & 124.77 & 10.50 & 5.1841 & 0.8960 & 866 & 756 \\
\hline 2014 & $3,6,9,12$ & 392,439 & $1,002,394$ & 117.70 & 120.13 & 124.42 & 11.00 & 5.1837 & 1.5028 & 990 & 900 \\
\hline 2015 & $3,6,9,12$ & 391,657 & $1,011,450$ & 117.00 & 119.00 & 121.35 & 11.00 & 5.0026 & 1.4915 & 990 & 900 \\
\hline 2016 & $3,6,9,12$ & 381,187 & $1,196,905$ & 103.00 & 116.63 & 122.51 & 10.75 & 5.0028 & 1.3497 & 949 & 863 \\
\hline Average & & 172,992 & 429,723 & 96.41 & 109.99 & 124.95 & 8.98 & 5.0166 & 3.9736 & 1026.23 & 783.58 \\
\hline
\end{tabular}


Table 3

Summary Statistics for Balance Sheet Costs. This table presents summary statistics for the balance sheet costs. The balance sheet costs are computed as the difference between the implied repo rate and the corresponding term repo rate and are expressed in basis points. Positive denotes the percentage of observations that are positive. The columns with headings $5 \%$, 50\%, and 95\% denote the 5 th. 50 th, and 95 th percentiles of the distribution. $N$ denotes the number of observations. The sample period is from June 3,1991 to December $30,2016$.

\begin{tabular}{|c|c|c|c|c|c|c|c|}
\hline Year & Mean & Positive & St. Dev. & $5 \%$ & $50 \%$ & $95 \%$ & $N$ \\
\hline 1992 & 183.77 & 100.00 & 167.72 & 31.71 & 113.02 & 528.93 & 253 \\
\hline 1993 & 46.85 & 83.79 & 69.89 & -99.89 & 49.91 & 159.63 & 253 \\
\hline 1994 & 165.89 & 99.21 & 132.68 & 40.41 & 124.32 & 467.30 & 252 \\
\hline 1996 & 86.96 & 96.43 & 52.77 & 17.47 & 78.57 & 174.41 & 252 \\
\hline 1997 & 212.89 & 100.00 & 134.77 & 44.44 & 186.21 & 430.68 & 250 \\
\hline 1998 & 125.20 & 95.60 & 117.25 & 11.21 & 89.20 & 359.27 & 250 \\
\hline 1999 & -53.48 & 16.40 & 52.64 & -133.38 & -62.48 & 29.46 & 250 \\
\hline 2000 & -17.49 & 41.27 & 68.04 & -116.28 & -31.02 & 98.02 & 252 \\
\hline 2001 & -71.97 & 10.71 & 67.53 & -182.62 & -65.04 & 13.27 & 252 \\
\hline 2002 & 39.59 & 58.33 & 129.29 & -143.07 & 32.88 & 295.14 & 252 \\
\hline 2003 & 110.75 & 86.11 & 109.28 & -37.14 & 97.64 & 347.82 & 252 \\
\hline 2005 & 28.37 & 76.40 & 40.60 & -32.21 & 28.30 & 96.69 & 250 \\
\hline 2006 & 22.51 & 73.20 & 43.09 & -44.23 & 22.61 & 99.01 & 250 \\
\hline 2007 & 25.51 & 76.89 & 50.89 & -55.70 & 29.18 & 86.32 & 251 \\
\hline 2008 & 63.18 & 61.66 & 196.91 & -92.46 & 15.82 & 384.31 & 253 \\
\hline 2009 & 181.82 & 100.00 & 113.72 & 72.31 & 143.83 & 429.02 & 252 \\
\hline 2010 & 141.25 & 100.00 & 88.64 & 61.28 & 116.23 & 347.38 & 253 \\
\hline 2011 & 107.57 & 98.81 & 79.26 & 25.90 & 88.72 & 284.04 & 253 \\
\hline 2012 & 65.09 & 99.21 & 30.67 & 29.70 & 59.46 & 126.39 & 253 \\
\hline 2013 & 66.69 & 98.02 & 35.57 & 17.15 & 64.91 & 118.06 & 252 \\
\hline 2014 & 49.97 & 95.63 & 35.58 & 0.64 & 43.12 & 114.57 & 252 \\
\hline 2015 & 57.48 & 97.63 & 33.86 & 11.90 & 55.83 & 107.76 & 253 \\
\hline 2016 & 59.82 & 96.43 & 34.52 & 10.80 & 57.55 & 123.18 & 252 \\
\hline All & 81.05 & 82.68 & 120.37 & -78.24 & 63.32 & 332.13 & 6,443 \\
\hline
\end{tabular}


Table 4

Results from Regressions of Balance Sheet Costs on Cost of Capital Measures. This table reports the results from regressions of the balance sheet cost measure on its lagged value, on quarter-end dummy variables, and on measures of the cost of debt and equity capital. Balance sheet costs are measured in basis points. March, June, September, and December are dummy variables that take a value of one for the respective months, and zero otherwise. Earnings/Price Ratio and Dividend Yield represent averages for the banks in the banking industry portfolio defined by the Fama-French 49 Industry Classification. Term Structure Slope denotes the basis-point difference between ten-year and three-month Treasury rates. Funding Cost denotes the marginal cost of funding bank assets and is computed as the basis-point change over the previous quarter in the average cost of funding earning assets for all banks as reported by FDIC. LiborTreasury Spread denotes the basis-point difference between the three-month Libor rate and the three-month Treasury bill rate. Swap Spread denotes the ten-year swap spread measured in basis points. The superscript * denotes significance at the ten-percent level; the superscript ${ }^{* *}$ denotes significance at the five-percent level. The $t$-statistics are based on the Newey-West (1987) heteroskedasticity and autocorrelation consistent estimate of the covariance matrix (five lags). The sample period is monthly from June 1991 to December 2016.

\begin{tabular}{l|cc}
\hline Variable & Coefficient & $t$-Stat \\
\hline Intercept & -22.4244 & -0.06 \\
Lagged Cost & 0.5534 & $7.37^{* *}$ \\
& & \\
March & 13.9473 & 0.67 \\
June & -19.0888 & -1.08 \\
September & -20.3773 & $-1.68^{*}$ \\
December & -43.6123 & $-2.06^{* *}$ \\
Earnings/Price Ratio & 286.4263 & $2.26^{* *}$ \\
Dividend Yield & -203.9691 & -0.10 \\
Term Structure Slope & 0.1535 & $2.29^{* *}$ \\
Funding Cost & 72.4798 & $2.38^{* *}$ \\
Libor-Treasury Spread & 0.3127 & $1.70^{*}$ \\
Swap Spread & -0.3519 & -1.52 \\
& & \\
\hline Adj. $R^{2}$ & & 0.431 \\
$N$ & & 307 \\
\hline
\end{tabular}


Table 5

Results from Regressions of Balance Sheet Costs on Capital Ratios. This table reports the results from regressions of the balance sheet cost measure on its lagged value and on contemporaneous and lagged changes in capital ratios. Balance sheet costs are measured in basis points. Tier 1 Ratio represents Tier 1 capital as a percentage of risk-weighted assets. Core Ratio represents Tier 1 capital as a percentage of average total assets minus ineligible intangibles. Equity ratio represents total equity capital as a percentage of total assets. Total Capital Ratio represents total risk-based capital as a percentage of risk-weighted assets. Non-Repo Equity represents total broker-dealer equity as a percentage of total assets, where the value of repo contracts is first subtracted out from the balance sheet. The first four capital ratios are averages over all banks using data provided by the FDIC. The fifth is computed using flow of funds data from Federal Reserve Board. We allow for quarterly fixed effects by including provided by the FDIC. The fifth is computed using flow of funds data from Federal Reserve Board. We allow for quarterly fixed effects by including
dummy variables that take a value of one for the first, second, third, and fourth quarters, respectively, and zero otherwise. The superscript $*$ denotes dummy variables that take a value of one for the first, second, third, and fourth quarters, respectively, and zero otherwise. The superscript * denotes (1987) heteroskedasticity and autocorrelation consistent estimate of the covariance matrix (five lags). The sample period is quarterly from June 1991 to December 2016

\begin{tabular}{|c|c|c|c|c|c|c|c|c|c|c|}
\hline Variable & Coefficient & $t$-Stat & Coefficient & $t$-Stat & Coefficient & $t$-Stat & Coefficient & $t$-Stat & Coefficient & $t$-Stat \\
\hline $\operatorname{Cost}_{t-1}$ & 0.4787 & $4.85^{* *}$ & 0.4806 & $5.22^{* *}$ & 0.4855 & $5.07^{* *}$ & 0.4806 & $4.84^{* *}$ & 0.4893 & $5.09^{* *}$ \\
\hline $\begin{array}{l}\Delta \text { Tier } 1 \text { Ratio }_{\mathrm{t}} \\
\Delta \text { Tier } 1 \text { Ratio }_{\mathrm{t}-1} \\
\Delta \text { Tier } 1 \text { Ratio }_{\mathrm{t}-2}\end{array}$ & $\begin{array}{r}85.6668 \\
-25.9852 \\
-37.6417\end{array}$ & 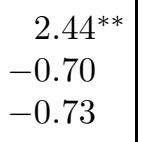 & & & & & & & & \\
\hline $\begin{array}{l}\Delta \text { Core Ratio }_{\mathrm{t}} \\
\Delta \text { Core Ratio }_{\mathrm{t}-1} \\
\Delta \text { Core Ratio }_{\mathrm{t}-2}\end{array}$ & & & $\begin{array}{r}244.1550 \\
-15.1301 \\
-191.3880\end{array}$ & $\begin{aligned} & 2.19^{* *} \\
- & 0.70 \\
- & 2.53^{* *}\end{aligned}$ & & & & & & \\
\hline $\begin{array}{l}\Delta \text { Equity Ratio }_{\mathrm{t}} \\
\Delta \text { Equity Ratio }_{\mathrm{t}-1} \\
\Delta \text { Equity Ratio }_{\mathrm{t}-2}\end{array}$ & & & & & $\begin{array}{r}169.2156 \\
-80.7738 \\
-167.2945\end{array}$ & $\begin{aligned} & 2.17^{* *} \\
- & 1.65 \\
- & 2.78^{* *}\end{aligned}$ & & & & \\
\hline $\begin{array}{l}\Delta \text { Total Capital Ratio }_{\mathrm{t}} \\
\Delta \text { Total Capital Ratio }_{\mathrm{t}-1} \\
\Delta \text { Total Capital Ratio }_{\mathrm{t}-2}\end{array}$ & & & & & & & $\begin{array}{r}74.4266 \\
-27.6095 \\
-26.1866\end{array}$ & $\begin{aligned} & 2.56^{* *} \\
- & 0.52 \\
- & 0.43\end{aligned}$ & & \\
\hline $\begin{array}{l}\Delta \text { Non-Repo Equity }_{\mathrm{t}} \\
\Delta \text { Non-Repo Equity }_{\mathrm{t}-1} \\
\Delta \text { Non-Repo Equity }_{\mathrm{t}-2}\end{array}$ & & & & & & & & & $\begin{array}{r}8.0894 \\
-0.0578 \\
-7.5170\end{array}$ & $\begin{array}{r}1.96^{*} \\
-0.01 \\
-1.37\end{array}$ \\
\hline Fixed Effects for Quarter & & Yes & & Yes & & Yes & & Yes & & Yes \\
\hline Adj. $R^{2}$ & & 0.204 & & 0.263 & & 0.286 & & 0.194 & & 0.197 \\
\hline$N$ & & 103 & & 103 & & 103 & & 103 & & 103 \\
\hline
\end{tabular}


Results from Regressions of Changes in Broker-Dealer Treasury Holdings, Asset Growth, and Changes in Leverage on Changes in Balance Sheet Costs. This table reports the results from regressions of the indicated dependent variable (shown in the column heading) on lagged values of the dependent variable and on lagged changes in balance sheet costs. Treasury holdings are expressed in $\$$ billions. Asset growth rate is expressed as a percentage. Leverage is expressed as a percentage. Balance sheet costs are measured in basis points. We allow for quarterly fixed effects by including dummy variables that take a value of one for the first, second, third, and fourth quarters, respectively, and zero otherwise. The superscript ${ }^{*}$ denotes significance at the ten-percent level; the superscript ${ }^{* *}$ denotes significance at the five-percent level. The $t$-statistics are based on the Newey-West (1987) heteroskedasticity and autocorrelation consistent estimate of the covariance matrix (five lags). The sample period is quarterly from June 1991 to December 2016 .

\begin{tabular}{|c|c|c|c|c|c|c|}
\hline \multirow[b]{2}{*}{ Variable } & \multicolumn{2}{|c|}{$\Delta$ Holdings } & \multicolumn{2}{|c|}{ Asset Growth Rate } & \multicolumn{2}{|c|}{$\Delta$ Leverage } \\
\hline & Coefficient & $t$-Stat & Coefficient & $t$-Stat & Coefficient & $t$-Stat \\
\hline $\begin{array}{l}\Delta \text { Holdings }_{\mathrm{t}-1} \\
\Delta \text { Holdings }_{\mathrm{t}-2} \\
\Delta \text { Holdings }_{\mathrm{t}-3}\end{array}$ & $\begin{array}{r}-0.1106 \\
0.1322 \\
0.2508\end{array}$ & $\begin{array}{l}-1.42 \\
1.29 \\
2.80^{* *}\end{array}$ & & & & \\
\hline $\begin{array}{l}\text { Asset Growth Rate }_{t-1} \\
\text { Asset Growth Rate }_{t-2} \\
\text { Asset Growth Rate }_{t-3}\end{array}$ & & & $\begin{array}{l}0.1680 \\
0.2193 \\
0.0538\end{array}$ & $\begin{array}{l}2.36^{* *} \\
1.80^{*} \\
0.68\end{array}$ & & \\
\hline $\begin{array}{l}\Delta \text { Leverage }_{t-1} \\
\Delta \text { Leverage }_{t-2} \\
\Delta \text { Leverage }_{t-3}\end{array}$ & & & & & $\begin{array}{r}-0.0767 \\
0.3979 \\
-0.0564\end{array}$ & $\begin{aligned} & 0.62 \\
& 3.29^{* *} \\
- & 0.79\end{aligned}$ \\
\hline $\begin{array}{l}\Delta \operatorname{Cost}_{t-1} \\
\Delta \operatorname{Cost}_{t-2} \\
\Delta \operatorname{Cost}_{t-3}\end{array}$ & $\begin{array}{r}-88.4581 \\
-67.0479 \\
6.9128\end{array}$ & $\begin{array}{l}-3.07^{* *} \\
-1.80^{*} \\
0.23\end{array}$ & $\begin{array}{l}-0.0043 \\
-0.0083 \\
-0.0055\end{array}$ & $\begin{array}{l}-0.93 \\
-2.35^{* *} \\
-1.02\end{array}$ & $\begin{array}{l}-0.0009 \\
-0.0023 \\
-0.0017\end{array}$ & $\begin{array}{l}-0.67 \\
-2.24^{* *} \\
-1.77^{*}\end{array}$ \\
\hline Fixed Effects for Quarter & & Yes & & Yes & & Yes \\
\hline $\begin{array}{l}\text { Adj. } R^{2} \\
N\end{array}$ & & $\begin{array}{r}0.370 \\
103\end{array}$ & & $\begin{array}{r}0.244 \\
103\end{array}$ & & $\begin{array}{r}0.185 \\
103\end{array}$ \\
\hline
\end{tabular}


Table 7

Results from Regression of Growth Rates in Total Swap Notional on Changes in Balance Sheet Costs. This table reports the results from regressions of the quarterly percentage change in the total notional amount of interest rate swaps for U.S. banks on its lagged values and on contemporaneous and lagged changes in balance sheet costs. Balance sheet costs are measured in basis points. We allow for monthly fixed effects by including dummy variables that take a value of one for January, February, March, etc., respectively, and zero otherwise. The superscript * denotes significance at the ten-percent level; the superscript $^{* *}$ denotes significance at the five-percent level. The $t$-statistics are based on the Newey-West (1987) heteroskedasticity and autocorrelation consistent estimate of the covariance matrix (five lags). The sample period is quarterly from June 1991 to December 2016.

\begin{tabular}{|c|c|c|}
\hline Variable & Coefficient & $t$-Stat \\
\hline $\begin{array}{l}\text { Swap Growth Rate } \text { t }_{t-1} \\
\text { Swap Growth Rate }_{t-2} \\
\text { Swap Growth Rate }_{t-3}\end{array}$ & $\begin{array}{l}0.05659 \\
0.21832 \\
0.39712\end{array}$ & $\begin{array}{l}0.34 \\
3.39^{* *} \\
3.19^{* *}\end{array}$ \\
\hline $\begin{array}{l}\text { Change in Cost } t \\
\text { Change in Cost } t-1 \\
\text { Change in Cost } t_{t-2} \\
\text { Change in Cost } t-3\end{array}$ & $\begin{array}{r}0.00014 \\
0.00021 \\
0.00004 \\
-0.00008\end{array}$ & $\begin{array}{l}1.84^{*} \\
2.51^{* *} \\
0.53 \\
-1.71^{*}\end{array}$ \\
\hline $\begin{array}{l}\text { Fixed Effects for Quarter } \\
\text { Adj. } R^{2} \\
N\end{array}$ & & $\begin{array}{r}\text { Yes } \\
0.193 \\
103\end{array}$ \\
\hline
\end{tabular}


Table 8

Results from Regression of Changes in Treasury Note Futures Open Interest on Changes in Balance Sheet Costs. This table reports the results from regressions of the monthly change in the open interest of Treasury note futures contracts on its lagged changes, on contemporaneous and lagged changes in trading volume, on contemporaneous and lagged values of the initial margin, and on contemporaneous and lagged changes in balance sheet costs. Open Interest denotes the average monthly open interest for the current five-year Treasury note futures contract. Volume denotes the average monthly volume for the current five-year Treasury note futures contract. Margin denotes the average initial margin for the current five-year Treasury note futures contract and is measured in dollars per contract. Cost denotes the balance sheet cost measure computed as the difference between the implied repo and repo rates. Balance sheet costs are measured in basis points. We allow for monthly fixed effects by including dummy variables that take a value of one for January, February, March, etc., respectively, and zero otherwise. The superscript ${ }^{*}$ denotes significance at the ten-percent level; the superscript ${ }^{* *}$ denotes significance at the five-percent level. The $t$-statistics are based on the Newey-West (1987) heteroskedasticity and autocorrelation consistent estimate of the covariance matrix (five lags). The sample period is monthly from June 1991 to December 2016.

\begin{tabular}{|c|c|c|}
\hline Variable & Coefficient & $t$-Stat \\
\hline $\begin{array}{l}\text { Change in Open Interest } t-1 \\
\text { Change in Open Interest } t_{t-2}\end{array}$ & $\begin{array}{l}-0.46409 \\
-0.49901\end{array}$ & $\begin{array}{l}-6.79^{* *} \\
-8.54^{* *}\end{array}$ \\
\hline $\begin{array}{l}\text { Change in Volume }_{t} \\
\text { Change in Volume }_{t-1} \\
\text { Change in Volume }_{t-2}\end{array}$ & $\begin{array}{r}-0.03464 \\
0.37069 \\
0.28599\end{array}$ & $\begin{array}{r}-0.37 \\
3.88^{* *} \\
2.75^{* *}\end{array}$ \\
\hline $\begin{array}{l}\operatorname{Margin}_{t} \\
\operatorname{Margin}_{t-1} \\
\operatorname{Margin}_{t-2}\end{array}$ & $\begin{array}{r}-46.98730 \\
-73.76279 \\
37.85035\end{array}$ & $\begin{array}{r}-1.00 \\
-1.00 \\
0.61\end{array}$ \\
\hline $\begin{array}{l}\text { Change in Cost } t \\
\text { Change in Cost } t-1 \\
\text { Change in Cost } t_{t-2}\end{array}$ & $\begin{array}{r}72.68979 \\
35.11487 \\
-101.77580\end{array}$ & $\begin{aligned} & 1.77^{*} \\
& 0.75 \\
- & 2.22^{* *}\end{aligned}$ \\
\hline Fixed Effects for Month & & Yes \\
\hline $\begin{array}{l}\text { Adj. } R^{2} \\
N\end{array}$ & & $\begin{array}{r}0.658 \\
307\end{array}$ \\
\hline
\end{tabular}


Table 9

Results from Regressions of Changes in Swap Spreads on Changes in Balance Sheet Costs. This table reports the results from individual regressions of changes in the $N$-year swap spread (for the value of $N$ shown in the column heading) on its lagged values, on contemporaneous and lagged changes in the two-year swap spread, and on contemporaneous and lagged changes in balance sheet costs. SS denotes the swap spread. Swap spreads and balance sheet costs are measured in basis points. We allow for quarterly fixed effects by including dummy variables that take a value of one for the first, second, third, and fourth quarters, respectively, and zero otherwise. The superscript * denotes significance at the ten-percent level; the superscript ${ }^{* *}$ denotes significance at the five-percent level. The $t$-statistics are based on the Newey-West (1987) heteroskedasticity and autocorrelation consistent estimate of the covariance matrix (five lags). The sample period is monthly from June 1991 to December 2016.

\begin{tabular}{|c|c|c|c|c|c|c|c|c|c|c|c|c|}
\hline \multirow[b]{2}{*}{ Variable } & \multicolumn{2}{|c|}{$N=5$} & \multicolumn{2}{|c|}{$N=7$} & \multicolumn{2}{|c|}{$N=10$} & \multicolumn{2}{|c|}{$N=15$} & \multicolumn{2}{|c|}{$N=20$} & \multicolumn{2}{|c|}{$N=30$} \\
\hline & Coeff & $t$-Stat & Coeff & $t$-Stat & Coeff & $t$-Stat & Coeff & $t$-Stat & Coeff & $t$-Stat & Coeff & $t$-Stat \\
\hline Intercept & -0.182 & -0.86 & -0.219 & -0.91 & -0.245 & -0.84 & -0.333 & -0.89 & -0.398 & -0.95 & -0.440 & -0.97 \\
\hline Change in $N$-Year $\mathrm{SS}_{\mathrm{t}-1}$ & -0.207 & $-2.92^{* *}$ & -0.095 & -1.56 & -0.075 & -0.91 & 0.039 & 0.43 & 0.037 & 0.34 & -0.021 & -0.22 \\
\hline Change in $N$-Year $\mathrm{SS}_{\mathrm{t}-2}$ & -0.135 & $-1.73^{*}$ & -0.081 & -1.10 & -0.023 & -0.29 & -0.156 & $-2.45^{* *}$ & -0.140 & $-1.86^{*}$ & -0.045 & -0.70 \\
\hline Change in $N$-Year $\mathrm{SS}_{\mathrm{t}-3}$ & -0.023 & -0.46 & -0.047 & -0.76 & -0.077 & -0.90 & -0.137 & $-2.02^{* *}$ & -0.020 & -0.27 & 0.006 & 0.07 \\
\hline Change in 2-Year $\mathrm{SS}_{\mathrm{t}}$ & 0.689 & $8.59^{* *}$ & 0.551 & $6.17^{* *}$ & 0.399 & $3.76^{* *}$ & 0.235 & $2.49^{* *}$ & 0.249 & $2.22^{* *}$ & 0.235 & $2.22^{* *}$ \\
\hline Change in 2-Year $\mathrm{SS}_{\mathrm{t}-1}$ & 0.191 & $3.80^{* *}$ & 0.116 & $2.60^{* *}$ & 0.006 & 0.08 & -0.005 & -0.05 & -0.075 & -0.65 & -0.002 & -0.02 \\
\hline Change in 2-Year $\mathrm{SS}_{\mathrm{t}-2}$ & 0.022 & 0.38 & -0.030 & -0.51 & -0.155 & $-2.09^{* *}$ & -0.165 & $-1.77^{*}$ & -0.134 & -1.21 & -0.189 & -1.60 \\
\hline Change in 2 -Year $\mathrm{SS}_{\mathrm{t}-3}$ & -0.054 & -1.04 & 0.030 & 0.56 & 0.066 & 0.99 & 0.141 & 1.58 & 0.052 & 0.41 & 0.028 & 0.18 \\
\hline Change in Cost ${ }_{t}$ & -0.001 & -0.50 & -0.004 & -1.16 & -0.005 & -1.11 & -0.015 & -1.60 & -0.019 & -1.55 & -0.023 & $-1.90^{*}$ \\
\hline Change in Cost $_{t-1}$ & 0.000 & 0.13 & 0.002 & 0.53 & 0.007 & $2.06^{* *}$ & 0.015 & $2.52^{* *}$ & 0.018 & $2.44^{* *}$ & 0.015 & $2.12^{* *}$ \\
\hline Change in Cost $_{t-2}$ & 0.005 & 1.62 & 0.006 & $2.08^{* *}$ & 0.001 & 0.23 & -0.001 & -0.15 & -0.003 & -0.40 & -0.013 & $-1.94^{*}$ \\
\hline Change in Cost $_{t-3}$ & 0.002 & 0.79 & -0.006 & -1.49 & -0.002 & -0.48 & -0.003 & -0.60 & -0.001 & -0.29 & -0.007 & -1.12 \\
\hline Adj. $R^{2}$ & & 0.578 & & 0.415 & & 0.257 & & 0.218 & & 0.167 & & 0.179 \\
\hline Number & & 307 & & 307 & & 307 & & 271 & & 271 & & 271 \\
\hline
\end{tabular}

